\title{
Application and validation of a 3-D calcium, chloride, and sulfate model in Lake Okeechobee
}

\author{
Kang-Ren $\mathrm{Jin}^{1 *}$, Mark D Shafer ${ }^{2}$ and Zhen-Gang $\mathrm{Ji}^{3}$
}

\begin{abstract}
Introduction: The calibration, verification, and validation of calcium $(\mathrm{Ca})$, chloride $(\mathrm{Cl})$, and sulfate $\left(\mathrm{SO}_{4}\right)$ module of the Lake Okeechobee Environment Model (LOEM) was completed. The integrated model could simulate $\mathrm{Ca}$, $\mathrm{Cl}$, and $\mathrm{SO}_{4}$ concentrations and transport due to wind driven currents and waves from 1 Oct 1999 to 30 Sept 2009 in Lake Okeechobee. The enhanced model was also used to estimate lake water quality effects resulting from different management scenarios that include discharges from planned aquifer storage and recovery (ASR) facilities.

Methods: The fate and transport processes of $\mathrm{Ca}, \mathrm{Cl}$, and $\mathrm{SO}_{4}$ are controlled by their reactivity and their hydrodynamic transport. Reactivity includes chemical, biological, and bio-uptake processes (IJRSA 33:2233-2260, 2012). Hydrodynamic transport includes advection of water current, diffusion, and turbulent mixing within the water column. The deposition and resuspension on the water-sediment bed interface is also included. The mathematical equations for describing $\mathrm{Ca}_{\text {, }}$ $\mathrm{Cl}$, and $\mathrm{SO}_{4}$ substances, including heavy metal and total organic carbon (TOC), are similar.
\end{abstract}

Results: Both the statistical results and the time series comparisons indicate that the simulation of $\mathrm{Ca}, \mathrm{Cl}$, and $\mathrm{SO}_{4}$ are generally simulated well by the LOEM. The root mean square error over the variance rage is $\mathrm{Cl}<18 \%, \mathrm{Ca}<35 \%$, and $\mathrm{SO}_{4}<19 \%$.

Conclusions: $\mathrm{Cl}, \mathrm{Ca}$, and $\mathrm{SO}_{4}$ concentrations in the lake were largely controlled by water temperature and lake evaporation. Inflows to the lake can also have localized effects on chloride variations. Shallow water depth and high evaporation contribute to high $\mathrm{Cl} / \mathrm{Ca} / \mathrm{SO}_{4}$ concentration in the lake.

Keywords: $\mathrm{Ca}$; $\mathrm{Cl}_{\text {; }} \mathrm{SO}_{4}$ modeling; Lake Okeechobee; Long-term simulation; Environmental modeling

\section{Introduction}

Sorption of $\mathrm{Ca}, \mathrm{Cl}$, and $\mathrm{SO}_{4}$ to sediments is one of the most important processes affecting their transport (Ji, 2008). An accurate description of hydrodynamic processes and sediment processes (Vermaat et al. 2000) is essential to describe the deposition and transport of $\mathrm{Ca}, \mathrm{Cl}$, and $\mathrm{SO}_{4}$.

$\mathrm{Ca}, \mathrm{Cl}$, and $\mathrm{SO}_{4}$ in excess concentrations can cause adverse effects in the chemical or environmental conditions of a water body. $\mathrm{Ca}, \mathrm{Cl}$, and $\mathrm{SO}_{4}$ are associated, at varying degrees, with suspended and deposited particles in the natural systems. Although $\mathrm{Ca}, \mathrm{Cl}$, and $\mathrm{SO}_{4}$ can be transported into the water bodies in dissolved forms, particulate phase of the $\mathrm{Ca}, \mathrm{Cl}$, and $\mathrm{SO}_{4}$ can be adsorbed onto fine sediment particles. Sediments are both a carrier and a possible source of $\mathrm{Ca}, \mathrm{Cl}$, and $\mathrm{SO}_{4}$ in aquatic systems. Sorption of $\mathrm{Ca}, \mathrm{Cl}$,

\footnotetext{
* Correspondence: kjin@sfwmd.gov

${ }^{1}$ Lead Scientist, South Florida Water Management District, P.O. Box 24680,

West Palm Beach, FL 33416-4680, USA

Full list of author information is available at the end of the article
}

and $\mathrm{SO}_{4}$ to suspended sediment is one of the important processes affecting their dynamic balance in a water body. $\mathrm{Ca}, \mathrm{Cl}$, and $\mathrm{SO}_{4}$ can be transported through a water body by suspended sediment, deposited to the bottom and/or resuspended from the sediment bed by chemical and hydrodynamic factors.

Due to the large variability of total suspended solid concentrations and the complicated sediment $\mathrm{Ca}, \mathrm{Cl}$, and $\mathrm{SO}_{4}$ interaction processes, the accuracy of modeling results varied significantly in past studies. For example, Thomann et al. (1991) modeled the fate and transport of PCB in the Hudson estuary and reported that the difference between data and modeled results are up to two orders of magnitude. Thomann et al. (1993) modeled cadmium concentrations in the Hudson River and only focused on long-term (e.g. year to year) behaviors. Kuwabara et al. (1999) described the processes affecting the benthic flux of trace minerals into the water column of San Francisco Bay. Ji et al. 
(2002) simulated sediment and minerals in Blackstone River, MA.

Under a storm event, the deposited sediment, along with $\mathrm{Ca}, \mathrm{Cl}$, and $\mathrm{SO}_{4}$, could be resuspended into the water column. Elimination of the $\mathrm{Ca}, \mathrm{Cl}$, and $\mathrm{SO}_{4}$ would still not remove the source on the sediment bed (Otsubo and Muraoka, 1987; Jin and Ji, 2005; Jin and Sun, 2007). The origins of $\mathrm{Ca}, \mathrm{Cl}$, and $\mathrm{SO}_{4}$ can be divided into point and nonpoint sources (Jin and Ji, 2004). Sometimes $\mathrm{Ca}, \mathrm{Cl}$, and $\mathrm{SO}_{4}$ are localized around the discharging location. In other cases, rivers and streams can carry the sediments and the $\mathrm{Ca}, \mathrm{Cl}$, and $\mathrm{SO}_{4}$ downstream for a long distance. Temporal variability of nonpoint sources is directly related to watershed hydrologic variability. High runoff is usually accompanied by high loads of sediments that may contain $\mathrm{Ca}, \mathrm{Cl}$, and $\mathrm{SO}_{4}$.

$\mathrm{Ca}, \mathrm{Cl}$, and $\mathrm{SO}_{4}$ in aquatic systems are removed through natural purification processes that dilute, transport, and remove $\mathrm{Ca}, \mathrm{Cl}$, and $\mathrm{SO}_{4}$. It is essential to understand the kinetics of reactants, the balance, and the transport of $\mathrm{Ca}, \mathrm{Cl}$, and $\mathrm{SO}_{4}$. It is also necessary to develop a tool to estimate the $\mathrm{Ca}, \mathrm{Cl}$, and $\mathrm{SO}_{4}$ impact on the environment under different scenarios.

The Comprehensive Everglades Restoration Program (CERP) includes an aquifer storage and recovery (ASR) study (CERP 2014). The CERP had originally conceptualized that up to 200 ASR wells could be capable of recharging and recovering up to 1 billion gallons of water per day from and into Lake Okeechobee and its surrounding watershed. Depending on water quality characteristics of the recovered ASR water, there is a potential for various effects on flora and fauna in Lake Okeechobee (Havens and Gawlik, 2005; Havens and James, 1997; 1999; Havens et al., 1995; 1996; 2001. Evaluation of environmental effects in Lake Okeechobee (James et al., 2008; James and Havens, 2005) must be taken into consideration due to the complex nature of the ecosystem, both in terms of its distinct ecological zones (pelagic, benthic, and littoral) and the diverse array of native biota that depends on these water resources (Aldridge et al., 1995; Havens et al., 1999).

\section{Methods}

\section{Governing equation}

The fate and transport processes of $\mathrm{Ca}, \mathrm{Cl}$, and $\mathrm{SO}_{4}$ are controlled by two factors (Hamrick, 1992; 1994; Hamrick and $\mathrm{Wu}, 1997)$ : their reactivity and their hydrodynamic transport. Reactivity includes chemical, biological, and bio-uptake processes (Chang et al., 2012). Hydrodynamic transport includes advection of water current, diffusion, and turbulent mixing within the water column (Cerco and Cole, 1994; Cerco et al. 2002). The deposition and resuspension on the water-sediment bed interface is also included. The mathematical equations for describing $\mathrm{Ca}, \mathrm{Cl}$, and $\mathrm{SO}_{4}$ substances, including heavy metal and total organic carbon
(TOC), are similar. The 3-D transport equation for total concentration $\mathrm{C}$ (dissolved plus particulate phases) is (Jin et al., 2000; Jin, et al., 2002, Jin et al., 2007):

$$
\begin{aligned}
& \partial_{t}(H C)+\partial_{x}(H u C)+\partial_{y}(H v C)+\partial_{z}(w C)-\partial_{z}\left(w_{s} f_{p} C\right) \\
= & \partial_{x}\left(H K_{H} \partial_{x} C\right)+\partial_{y}\left(H K_{H} \partial_{y} C\right)+\partial_{z}\left(\frac{K_{v}}{H} \partial_{z} C\right)+R+Q_{c}
\end{aligned}
$$

where $H=$ water depth; $u, v, w=$ velocity components, and $w_{\mathrm{s}}=$ sediment settling velocity.

$K$ vertical and horizontal mixing coefficient

$R$ reactivity of chemical and biological processes

$Q_{\mathrm{c}}=$ external $\mathrm{Ca}, \mathrm{Cl}$, and $\mathrm{SO}_{4}$ sources and sinks, $x$ and

$y=$ cartesian coordinates in the horizontal directions

$\mathrm{z}$ = sigma coordinate in the vertical direction.

As discussed before, the concentration of a $\mathrm{Ca}, \mathrm{Cl}$, and $\mathrm{SO}_{4}$ substance is composed of a dissolved component, $C_{\mathrm{d}}$, and a particulate component, $C_{\mathrm{p}}$ :

$$
C=C_{\mathrm{d}}+C_{\mathrm{p}}
$$

The particulate component can be expressed as a product of the $\mathrm{Ca}, \mathrm{Cl}$, and $\mathrm{SO}_{4}$ solid phase concentration, $r$, and the sediment concentration, $S$ :

$$
C_{p}=r \times S
$$

The $\mathrm{Ca}, \mathrm{Cl}$, and $\mathrm{SO}_{4}$ solid phase concentration, $\mathrm{r}$, is expressed in solid dry weight. For a given volume of sampled water, the $\mathrm{Ca}, \mathrm{Cl}$, and $\mathrm{SO}_{4}$ solid phase concentration is defined as follows:

$$
r=\frac{\text { Mass of toxics sorbed to sediment in } \mu \mathrm{g} \text { or } \mathrm{mg}}{\text { Mass of sediment in } \mathrm{mg} \text { or } \mathrm{g}}
$$

Assuming that equilibrium exists between the dissolved and particulate phases, which are usually valid in $\mathrm{Ca}, \mathrm{Cl}$, and $\mathrm{SO}_{4}$ modeling studies, the partition coefficient, $P$, is defined as follows:

$$
\begin{aligned}
P & =\frac{\text { Toxics sorbed to sediment (mass of toxics/mass of sediment) }}{\text { Dissolved toxics (mass of toxics/water volume) }} \\
& =\frac{r}{C_{d}}
\end{aligned}
$$

Equation (5) indicates that the partition coefficient is the ratio of the $\mathrm{Ca}, \mathrm{Cl}$, and $\mathrm{SO}_{4}$ in the particulate phase (sorbed to the sediment) to the $\mathrm{Ca}, \mathrm{Cl}$, and $\mathrm{SO}_{4}$ in the dissolved phase. The partition coefficient is usually expressed as $1 / \mathrm{g}$ or $1 / \mathrm{mg}$. The value of the partition coefficient for a given substance is affected by a number of factors. Some empirical evidence has suggested that the partition coefficient is inversely related to the sediment concentration, while in other cases, the partition coefficients are independent of sediment 
concentrations (O'conner 1988; Ji et al., 2002; Ji 2008). In order to accurately calculate the dissolved and particulate phases, measured data should be used to estimate the values of $P$.

From measured data, the partition coefficient can be estimated as follows:

$$
P=\frac{C_{\mathrm{p}}}{C_{\mathrm{d}}} \frac{1}{S}
$$

The meaning of $P$ becomes apparent in Equation (6); the partition coefficient is the ratio of the particulate concentration to the dissolved concentration per unit concentration of a suspended solid. For example, measured data indicate that metals in the Blackstone River, MA, have partition coefficients varying from 0.1 to $1.0 \mathrm{l} / \mathrm{mg}$ (Ji et al., 2002).

The particulate fraction of a $\mathrm{Ca}, \mathrm{Cl}$, and $\mathrm{SO}_{4}\left(f_{\mathrm{p}}\right)$ and the dissolved fraction of a $\mathrm{Ca}, \mathrm{Cl}$, and $\mathrm{SO}_{4}\left(f_{\mathrm{d}}\right)$ are defined as follows:

$$
\begin{aligned}
& f_{\mathrm{p}}=\frac{C_{\mathrm{p}}}{C}=\frac{P S}{\theta+P S} \\
& f_{\mathrm{d}}=\frac{C_{\mathrm{d}}}{C}=\frac{\theta}{\theta+P S}=1-f_{\mathrm{p}}
\end{aligned}
$$

where $\theta$ is the porosity (approximately 1 for the water column). The product P.S is a dimensionless parameter. The distribution of a $\mathrm{Ca}, \mathrm{Cl}$, and SO4ant between dissolved and particulate phases therefore depends on the partition coefficient and the sediment concentration. For a single metal element, there can be a variety of chemical complexes. In most measurements and simulation models, however, all dissolved metal complexes are lumped with the free ion to give the total dissolved metal concentration, and all particulate metal complexes are lumped with all sorbed species to give the total particulate metal concentration (AEE 2012).

Equation (1) includes the sediment settling term, $\partial_{z}\left(w_{s} f_{p} C\right)$. In Equation (1), the total $\mathrm{Ca}, \mathrm{Cl}$, and $\mathrm{SO} 4$ concentration, $C$, is modeled, instead of calculating the dissolved and the particulate phases separately. Equations (7) and (8) specify $C_{\mathrm{d}}$ and $C_{\mathrm{p}}$, after $C$ and the particulate fraction, $f_{\mathrm{p}}$, are known. It is the particulate fraction $\left(f_{\mathrm{p}}\right)$ and the sediment settling velocity $\left(w_{\mathrm{s}}\right)$ that link the $\mathrm{Ca}, \mathrm{Cl}$, and $\mathrm{SO}_{4}$ with the suspended sediment concentration. The sediment concentration, as shown in Equation (7), affects the particulate fraction and thus affects the settling and transport of the $\mathrm{Ca}, \mathrm{Cl}$, and $\mathrm{SO}_{4}$ described in Equation (1). In the modeling of heavy metals, the fate and decay mechanisms are usually neglected. In this sense, the modeling of metals is simpler than the modeling of some TOCs.
Vertical boundary conditions for the transport Equation (9) (Ji, 2008) are the following:

$$
\begin{gathered}
-\frac{K_{V}}{H} \partial_{z} C-w_{\mathrm{s}} f_{\mathrm{p}} C=F_{\mathrm{o}}, \quad \text { at water-sediment bed interface }(z \approx 0) \\
-\frac{K_{V}}{H} \partial_{\mathrm{z}} C-w_{\mathrm{s}} f_{\mathrm{p}} C=0, \quad \text { at the water surface }(z=1)
\end{gathered}
$$

The net flux of $\mathrm{Ca}, \mathrm{Cl}$, and $\mathrm{SO}_{4}$ from the sediment bed to the water column, $F_{\mathrm{o}}$, is given by:

$$
\begin{aligned}
F_{\mathrm{o}}= & \max \left(J_{\mathrm{o}}, 0\right)\left(\frac{f_{\mathrm{p}}^{\mathrm{b}}}{S^{\mathrm{b}}}+\varepsilon_{\mathrm{r}} \frac{\rho_{\mathrm{w}}}{\rho_{\mathrm{s}}} f_{\mathrm{d}}^{\mathrm{b}}\right) C^{\mathrm{b}} \\
& +\min \left(J_{\mathrm{o}}, 0\right)\left(\frac{f_{\mathrm{p}}^{\mathrm{w}}}{S^{\mathrm{w}}}+\varepsilon_{\mathrm{d}} \frac{\rho_{\mathrm{w}}}{\rho_{\mathrm{s}}} f_{\mathrm{d}}^{\mathrm{w}}\right) C^{\mathrm{w}}
\end{aligned}
$$

where the $\mathrm{w}$ and $\mathrm{b}$ superscripts define water column and sediment bed conditions at the water column-sediment bed interface, respectively, $\rho_{\mathrm{s}}$ is sediment density, $\rho_{\mathrm{w}}$ is water density, and $\varepsilon_{\mathrm{r}}$ and $\varepsilon_{\mathrm{d}}$ are the sediment bed void ratios under conditions of resuspension and deposition, respectively (Tetra Tech, 1998, 1999, 2000). $J_{\mathrm{o}}$ is the net sediment flux from the bed to the water column. This form of net flux consistently accounts for entrainment and expulsion of water and dissolved $\mathrm{Ca}, \mathrm{Cl}$, and $\mathrm{SO}_{4}$ from and to the bed due to sediment resuspension and deposition (Jin and Wang, 1998; Jin et al., 2000; Jin and Ji, 2001; Jin et al., 2002).

\section{Model setup}

Major external forcings that are used to drive the LOEM hydrodynamic and $\mathrm{Ca}, \mathrm{Cl}$, and $\mathrm{SO} 4$ model include wind velocity, solar radiation, rainfall, lake inflows/outflows, inflow/outflow temperatures, air temperature, relative humidity, and $\mathrm{Ca}, \mathrm{Cl}$, and $\mathrm{SO}_{4}$ concentrations of inflows. Rainfall, air temperature, relative humidity, and solar radiation data were collected every $15 \mathrm{~min}$ at four in-lake stations: LZ40, L001, L005, and L006 (Figure 1). Station LZ40 is located near the center of the lake. Hourly meteorological data at LZ40 are used in the LOEM model. Tributaries include 20 inflows and outflows (Jin et al. 2007). Their daily flow rates are measured by the USACE and SFWMD.

The measured data used for model-data comparison are water surface elevation and water temperature. Both the root mean square error (RMS) and the relative error are used to evaluate model performance. The RMS is the average of the squared differences between observed and predicted values. The RMS error is widely used to evaluate model performance. A RMS error of zero is ideal. In the hydrodynamic and water quality modeling (Havens and James, 2005; Havens et al., 2004), it is often useful to express the observation-prediction discrepancies in percentage to measure the model performance. The relative RMS error (RRE) is defined as the ratio of RMS error to the observed change: 


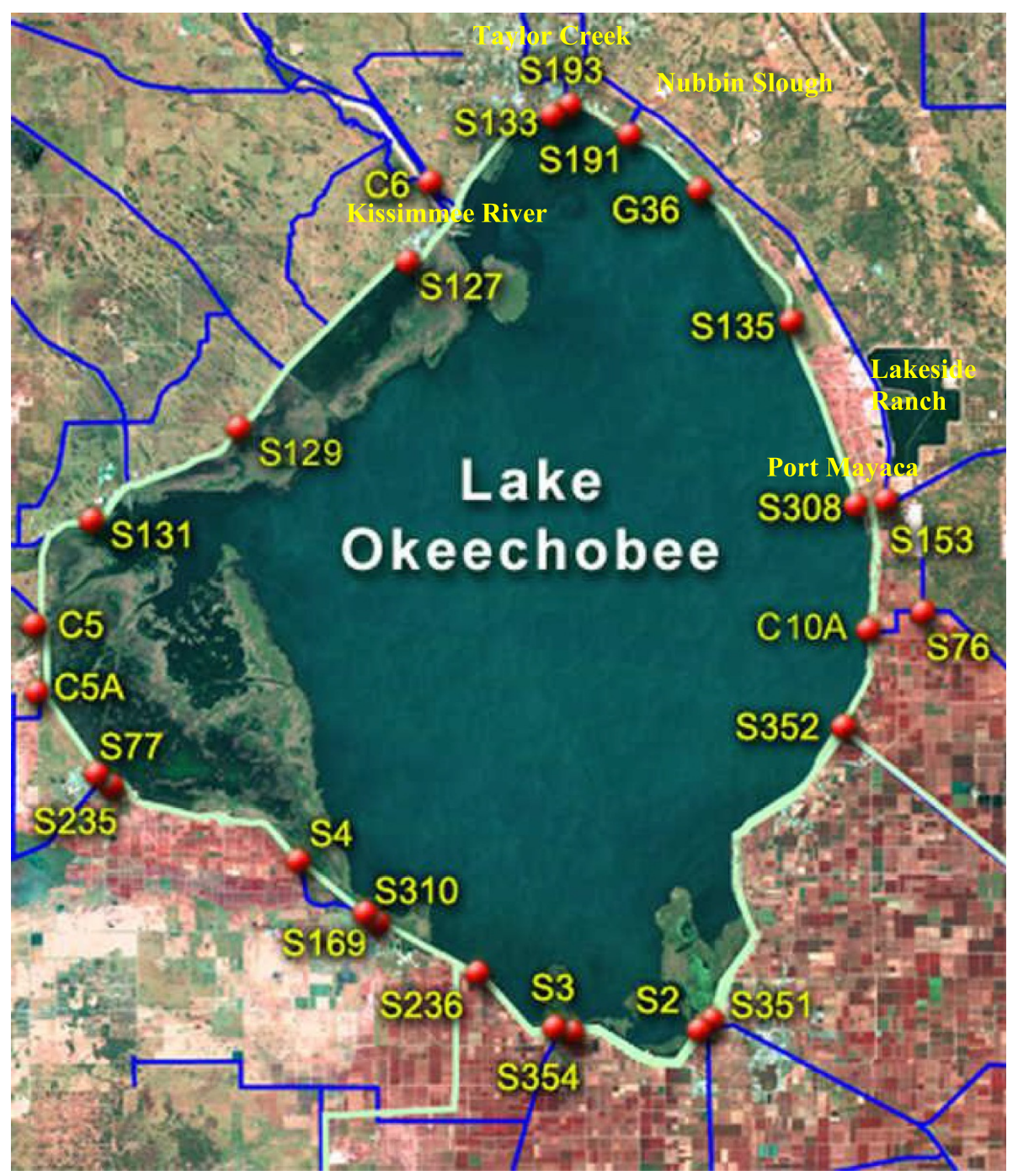

Figure 1 Lake Okeechobee data collection sites.

$$
\begin{aligned}
R R E & =\frac{R M S \text { error }}{\text { Observed change }} \times 100 \\
& =\frac{\sqrt{\frac{1}{N} \sum_{n=1}^{N}\left(O^{n}-P^{n}\right)^{2}}}{O_{\max }-O_{\min }} \times 100
\end{aligned}
$$

where

$N=$ number of observed-predicted pairs

$O^{n}=$ the value of the nth observed data

$P^{n}=$ the value of the nth predicted data

$O_{\max }=$ maximum value of observations

$\mathrm{O}_{\text {min }}=$ minimum value of observations

$O_{\max }-O_{\min }$ is the range of the observation data, and $N$ is the total number of the data points. The relative error provides an overall measurement of the model performance. The consistency between model predictions and observations is determined qualitatively by comparison plots for the various parameters and by statistical analysis tools. The LOEM model was initialized once and run continuously through the simulation period. Boundary conditions and loads were updated on a daily basis. Integration time-step was $180 \mathrm{~s}$. Output from the model was stored at 1-day increments. It takes about $40 \mathrm{~h}$ of CPU time to conduct a 10-year simulation on a Xeon $3.2 \mathrm{GHz}$ PC.

\section{Model results}

Hydrodynamics and sediment (total suspended solid)

In the hydrodynamic modeling, the water inflow and outflow are required for the mass balance in the lake. The measured daily flow rate data were used as time series boundary conditions to drive the model. Water 
evaporation is also an important factor for the water balance in the lake. The LOEM calculates the water evaporation rate based on measured air temperature, relative humidity, air pressure, wind speed, and the modeled water temperature. Figure 2 shows a sample comparison between the modeled and the measured water depth at LZ40. The red line represents the measured data and the black line represents the model result. The relative RMS error is $4.6 \%$. It is evident that the model simulated the lake depth very well.

There are 25 stations in the lake that have regular monitoring of water quality data, including water temperature, TSS, $\mathrm{Ca}, \mathrm{Cl}$, and $\mathrm{SO}_{4}$ (Phlips, et al., 1993; Murphy and Yesaki, 1983; Figure 3). Data from these stations are used for model-data comparison to evaluate the model performance. Both the statistical results (Table 1) and the time series comparisons (Figure 4) indicate that the LOEM model simulated T, TSS, $\mathrm{Ca}, \mathrm{Cl}$, and $\mathrm{SO}_{4}$ very well with mean relative errors of $17.4 \%$, $34.1 \%$, and $18.9 \%$ for $\mathrm{Cl}, \mathrm{Ca}$, and $\mathrm{SO}_{4}$, respectively.

\section{Results and discussion}

Sediment transport, deposition, and resuspension processes are important to the understanding of eutrophication; $\mathrm{Ca}, \mathrm{Cl}$, and $\mathrm{SO}_{4}$ transport; sediment bed erosion; siltation; and waste disposal. To understand sediment transport processes, it is critical to have good knowledge of the hydrodynamic processes.

Total suspended solids (TSS) influence density, light climate, and nutrient availability in lakes. Solids also may carry other pollutants into water bodies. Nutrients and $\mathrm{Ca}, \mathrm{Cl}$, and $\mathrm{SO}_{4}$ chemicals may attach to sediment particles on land and can be attached to the particles into surface waters where the pollutants may settle with the sediment or detach and become soluble in the water column. Increased TSS reduces light penetration in the water column affecting water temperature, which in turn affects biological and chemical reaction rates. Light climate in the water column also directly affects algae and vegetation growth. Nutrient concentrations also are affected by TSS through sorption and settling (Jin and Sun 2007).

The LOEM sediment module has been calibrated, verified, and validated using the sediment data in 2000, 2001, and 2002, respectively (Jin and Ji, 2004, 2005; Ji and Jin, 2006). The model parameter values and model sensitivity tests are also discussed in these studies. The modeled sediment concentrations from 1 Oct 1999 to 30 Sept 2009 for 3,653 days at the 25 monitoring stations were reasonable (Tables 1, 2, 3, 4, 5). For example, the relative error of modeled sediment concentration (TSS) at L006 is $14.5 \%$ (Table 2).

\section{Modeling results}

As an example, the model-data comparison of $\mathrm{Ca}, \mathrm{Cl}$, $\mathrm{SO}_{4}$, and TSS at LZ40 from 1 Oct 1999 to 30 Sept 2009 for 3,653 days is presented (Figure 4); the green lines are the results from the benchmark run, which is used for model calibration and verification. The panels of $\mathrm{Ca}, \mathrm{Cl}$,

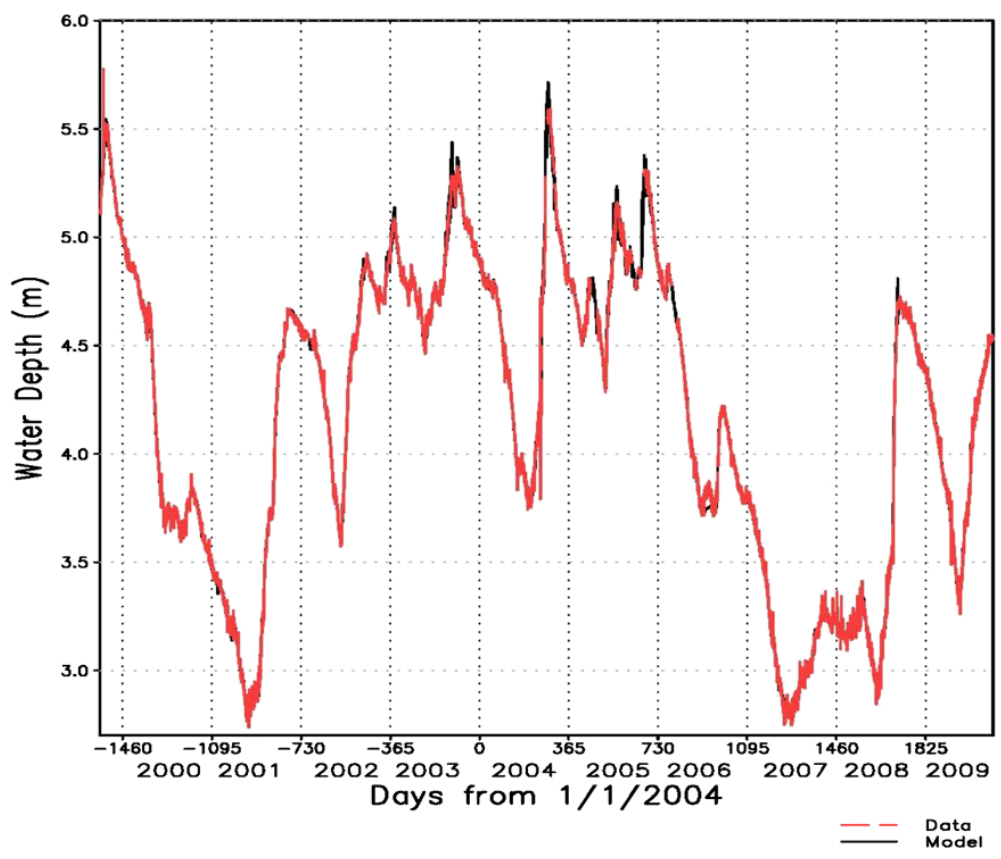

Figure 2 Modeled and measured lake surface elevation at LZ40 from 1 Oct 1999 to 30 Sept 2009. 


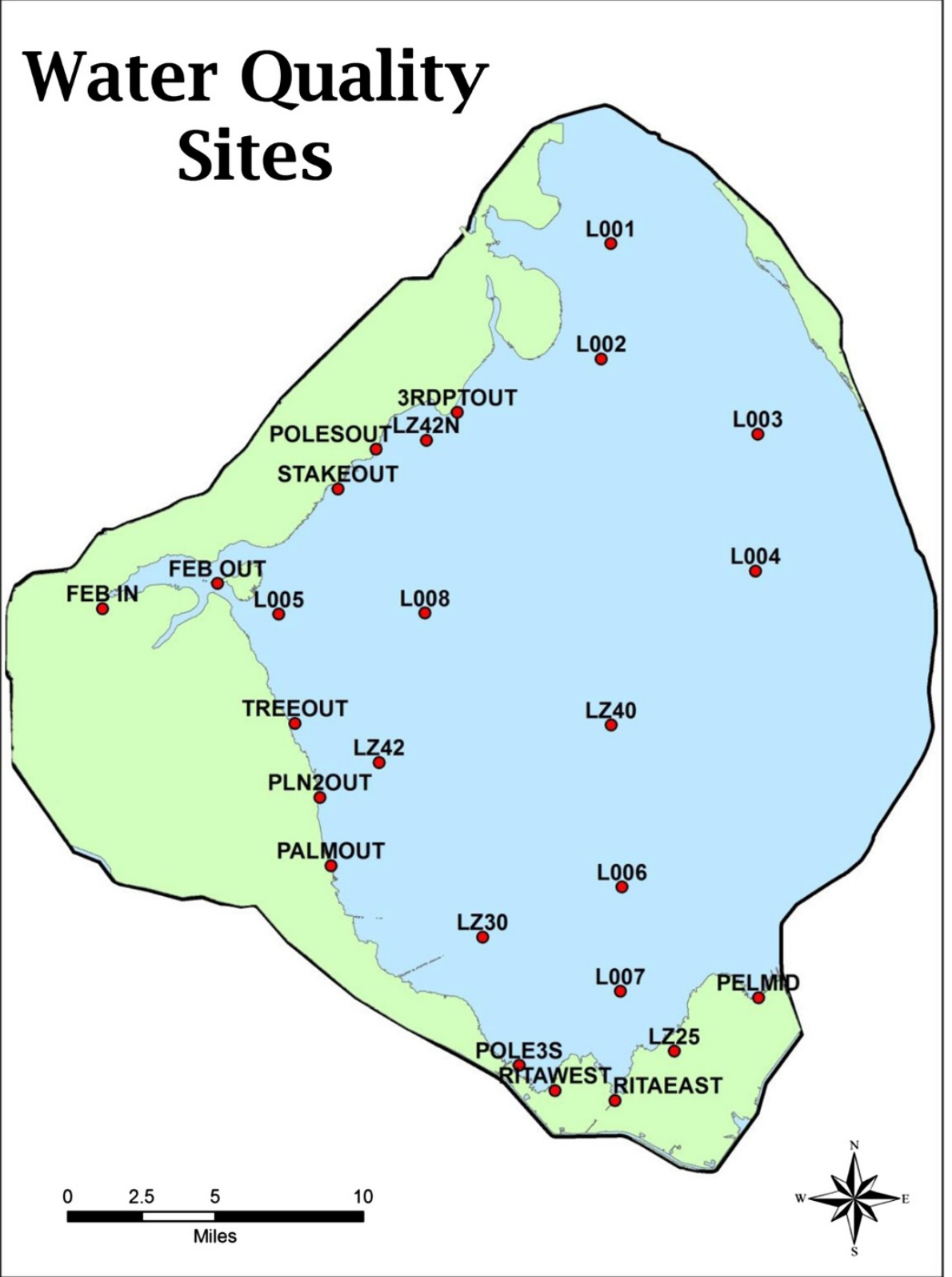

Figure 3 In lake water quality monitoring stations.

and $\mathrm{SO}_{4}$ indicate that these three constituents are generally simulated well by the LOEM.

Both the statistical results and the time series comparisons indicate that the LOEM simulated T (10\%), TSS, $\mathrm{Ca}, \mathrm{Cl}$, and $\mathrm{SO}_{4}$ well with the RMSE (T) $<10 \%$; RMSE (TSS) <27\%; RMSE (Cl) <18\%; RMSE (Ca) <35\%; and RMSE $\left(\mathrm{SO}_{4}\right)<19 \%$ (Tables 2, 3, 4, 5). As an example, Figure 4 gives the model-data comparison of $\mathrm{Ca}, \mathrm{Cl}$, SO4, and TSS at LZ40 from 1 Oct 1999 to 30 Sept 2009 for 3,653 days. In Figure 4, the green lines are the results from the benchmark run, which is the benchmark case for model calibration and verification. The panels of $\mathrm{Ca}$, $\mathrm{Cl}$, and $\mathrm{SO}_{4}$ in Figure 4 indicate that these three constituents are generally simulated well by the LOEM.

The lake experienced a prolonged drought in 2007 and 2008. During these two years, water levels were quite low (Figure 2). High concentrations of $\mathrm{Ca}, \mathrm{Cl}$, and $\mathrm{SO}_{4}$ were observed, and the increased concentration was accurately captured by the LOEM (Figure 4). Model sensitivity analysis indicates that $\mathrm{Cl}$ (along with $\mathrm{Ca}$ and $\mathrm{SO}_{4}$ ) concentrations in the lake were largely controlled by water temperature and lake evaporation. Higher 
Table 1 Error analysis of observed and modeled water temperature at the 25 stations from 1999 to 2009

\begin{tabular}{|c|c|c|c|c|c|c|c|}
\hline Station number & Station name & $\begin{array}{l}\text { Number of } \\
\text { data points }\end{array}$ & $\begin{array}{l}\text { Observed } \\
\text { mean }\left({ }^{\circ} \mathrm{C}\right) \\
\end{array}$ & $\begin{array}{l}\text { Modeled } \\
\text { mean }\left({ }^{\circ} \mathrm{C}\right) \\
\end{array}$ & RMS error $\left({ }^{\circ} \mathrm{C}\right)$ & $\begin{array}{l}\text { Observed } \\
\text { change }\left({ }^{\circ} \mathrm{C}\right)\end{array}$ & RER (\%) \\
\hline 1 & L006 & 74 & 24.7 & 25.3 & 1.7 & 20.7 & 8.6 \\
\hline 2 & L001 & 70 & 24.9 & 25.5 & 1.9 & 18.7 & 10.5 \\
\hline 3 & LZ40 & 72 & 24.4 & 24.9 & 1.7 & 17.6 & 9.9 \\
\hline 4 & L005 & 72 & 25.4 & 25.5 & 1.7 & 17.2 & 10.1 \\
\hline 5 & 3RDPTOUT & 60 & 25.2 & 24.5 & 1.8 & 17.5 & 10.7 \\
\hline 6 & KBAROUT & 43 & 24.2 & 24.0 & 2.1 & 19.3 & 11.0 \\
\hline 7 & L002 & 68 & 25.3 & 25.1 & 1.6 & 17.9 & 9.3 \\
\hline 8 & L003 & 73 & 24.4 & 24.8 & 1.6 & 19.2 & 8.5 \\
\hline 9 & L004 & 71 & 24.2 & 24.8 & 2.0 & 18.4 & 11.3 \\
\hline 10 & L007 & 63 & 24.6 & 24.3 & 1.4 & 20.7 & 7.1 \\
\hline 11 & L008 & 72 & 24.9 & 25.1 & 1.6 & 16.4 & 9.9 \\
\hline 12 & LZ2 & 63 & 25.4 & 25.3 & 2.3 & 18.8 & 12.2 \\
\hline 13 & LZ25 & 55 & 24.8 & 23.9 & 1.8 & 18.8 & 9.6 \\
\hline 14 & LZ30 & 73 & 24.9 & 24.9 & 1.5 & 19.3 & 7.9 \\
\hline 15 & LZ42 & 72 & 24.8 & 25.1 & 1.5 & 19.7 & 7.8 \\
\hline 16 & LZ42N & 65 & 25.3 & 24.6 & 1.7 & 18.0 & 9.4 \\
\hline 17 & PALMOUT & 61 & 24.9 & 24.7 & 1.6 & 16.9 & 9.7 \\
\hline 18 & PELMID & 61 & 24.9 & 24.1 & 1.5 & 19.1 & 8.1 \\
\hline 19 & PLN2OUT & 70 & 25.2 & 25.3 & 1.7 & 17.5 & 9.9 \\
\hline 20 & POLE3S & 65 & 25.2 & 24.6 & 1.5 & 17.7 & 8.8 \\
\hline 21 & POLESOUT & 61 & 25.6 & 24.7 & 2.0 & 18.9 & 10.7 \\
\hline 22 & RITAEAST & 69 & 25.6 & 25.0 & 1.7 & 18.2 & 9.3 \\
\hline 23 & RITAWEST & 65 & 25.3 & 24.6 & 1.6 & 18.6 & 8.9 \\
\hline 24 & STAKEOUT & 62 & 25.4 & 24.6 & 1.8 & 18.3 & 10.0 \\
\hline \multirow[t]{2}{*}{25} & TREEOUT & 63 & 24.6 & 24.6 & 1.4 & 20.5 & 7.0 \\
\hline & Total Mean & & 25.0 & 24.8 & 1.7 & 18.5 & 9.5 \\
\hline
\end{tabular}

chloride concentrations in the summer and fall seasons were largely due to stronger water evaporation from the lake surface. Inflows to the lake can also have localized effects on chloride variations. Shallow water depth and high evaporation contribute to high $\mathrm{Cl}$ concentration in the lake (Figures 5, 6, 7).

In the fall of 2002, large fluctuations of $\mathrm{Ca}, \mathrm{Cl}$, and $\mathrm{SO}_{4}$ were observed in the measured data showed at L004. The concentrations were lowered dramatically due to large inflows into the lake (Figure 4). The large amount of inflow diluted the in-lake concentration of $\mathrm{Ca}, \mathrm{Cl}$, and $\mathrm{SO}_{4}$.

Water depth (EL) and measured chloride concentration (Cl) at LZ40 from 1 Oct 1999 to 30 Sept 2009 are inversely related (Figure 5 ). The chloride values shown in the figure are calculated in this way: $\mathrm{Cl}^{\prime}=\mathrm{Cl} \times 0.05+1.5$. This is done in order to allow $\mathrm{Cl}^{\prime}$ and the water depth to be shown together. For example, a $\mathrm{Cl}$ value of $80 \mathrm{mg} / \mathrm{l}$ leads to a $\mathrm{Cl}^{\prime}$ value of 5.5 . Because the variation of chloride concentration lags behind the water depth variation, the time of chloride concentration is subtracted by 51 days to better align the spikes of $\mathrm{Cl}$ and EL. This time, shift moves the spikes of the $\mathrm{Cl}$ leftward by 51 days.

When the lake is shallow and its volume is small, the $\mathrm{Cl}$ concentration is high. When the lake water depth is large, the $\mathrm{Cl}$ concentration is low. Thus, the lake volume is a critical factor to the $\mathrm{Cl}$ concentration.

The factor that dominates lake water budget is water evaporation. About $70 \%$ of the lake's water leaves the lake by evaporation (James and McCormick 2012). High evaporation reduces lake volume (water depth) and increases the $\mathrm{Cl}$ concentration. This mechanism explains why low lake volume leads to high $\mathrm{Cl}$ concentration.

Because of the dilution and concentration effects of water volume on ions in Lake Okeechobee, water depth and $\mathrm{Cl}, \mathrm{Ca}$, and $\mathrm{SO}_{4}$ concentrations are strongly 

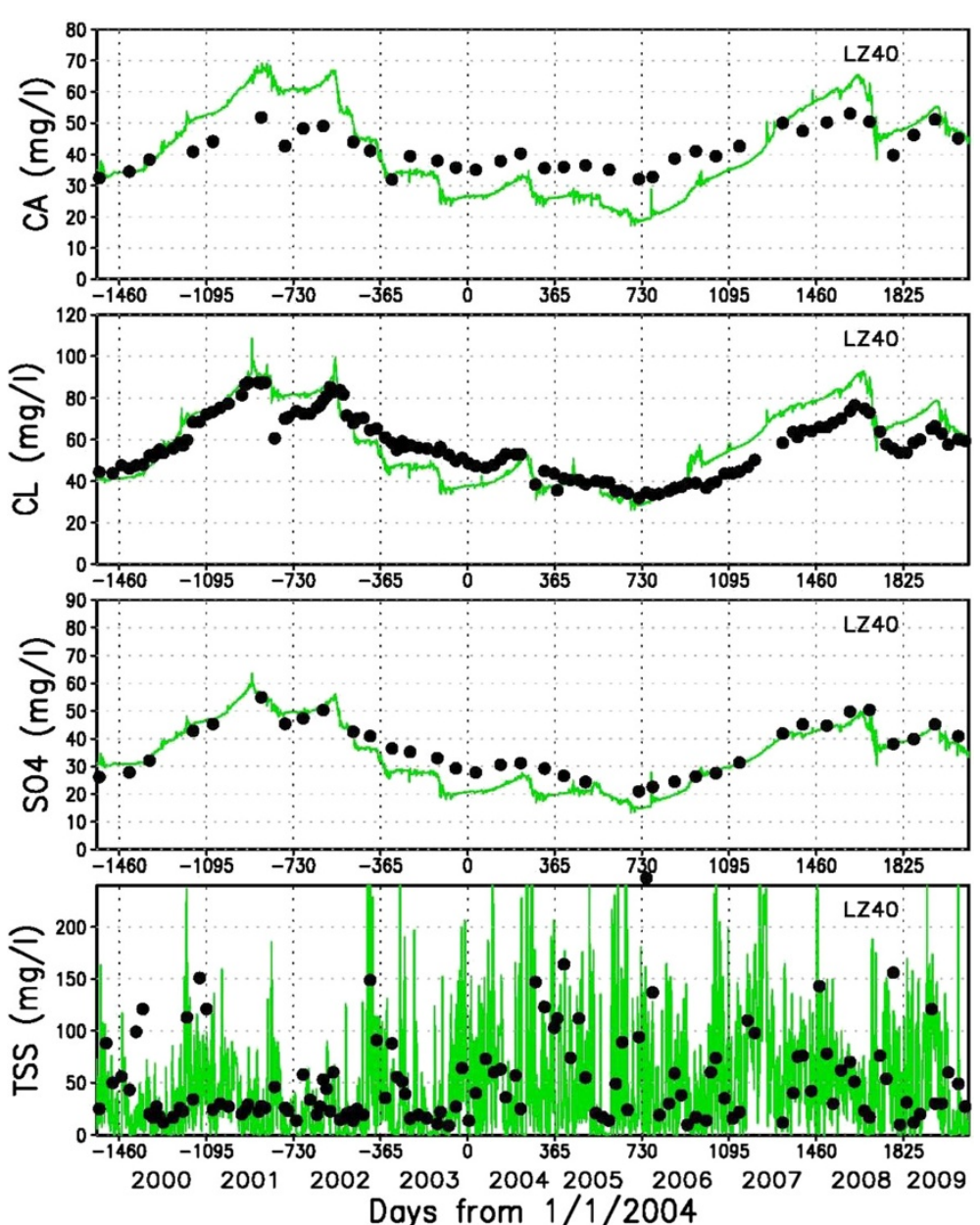

Figure 4 Model-data comparisons. Model-data comparisons of Ca, Cl, SO4, and TSS at LZ40 from 1 Oct 1999 to 30 Sept 2009. The black dots are measured data. The green lines are modeled results from the benchmark run.

correlated (Table 6: LZ40). When the $\mathrm{Cl}$ concentration lags behind the water depth by 51 days, the correlation coefficient is a maximum of -0.70 , clearly indicating a strong correlational lag between the two. When there is no time lagging between the two, the correlation coefficient is only -0.60 . This finding is also consistent with the one concluded in Figures 6 and 7.

Similar strong correlations between the water depth and the $\mathrm{Ca}$ and $\mathrm{SO}_{4}$ concentrations exist (Table 6). This suggests that variations of $\mathrm{Ca}$ and $\mathrm{SO}_{4}$ concentrations are also strongly controlled by lake evaporation. When the $\mathrm{Ca}$ concentration lags behind the water depth by 51 days; the correlation coefficient is a maximum of -0.83 . There are also negative correlations between water depth and $\mathrm{Cl}$ and water depth and $\mathrm{SO}_{4}$ concentrations. This suggests that variations of $\mathrm{Cl}$ and $\mathrm{SO}_{4}$ concentrations are also strongly controlled by lake evaporation.
To study the long-term variations of chloride, calcium, and sulfate concentrations in the lake, more than 30 years of measured data (SFWMD, 2011) was analyzed. Figure 8 gives the measured chloride concentration at L002 for 37 years, from 1972 to 2009. Figure 8 shows that in the past 4 decades, the lake's $\mathrm{Cl}$ concentration generally exhibited a downward trend. The mean values were reduced by about one half, from approximately $90 \mathrm{mg} / \mathrm{l}$ in the early 1970 s to approximately $40 \mathrm{mg} / \mathrm{l}$ in the 2000s. Figure 8 gives the measured sulfate concentration at L002 for 35 years, from 1974 to 2009. It shows a downward trend similar to the one in Figure 8 for $\mathrm{Cl}$. The mean $\mathrm{SO}_{4}$ values were reduced by about half, from around $55 \mathrm{mg} / \mathrm{l}$ to about $22 \mathrm{mg} / \mathrm{l}$, in the past 4 decades. The measured calcium concentration at L002 for 37 years (1992 to 2009) is also presented in Figure 8. Ca's mean values were also reduced in the past 4 decades (James and McCormick, 2012). 
Table 2 Error analysis of observed and modeled total suspended solid (TSS) at the 25 stations from 1999 to 2009

\begin{tabular}{|c|c|c|c|c|c|c|c|}
\hline Station number & Station name & $\begin{array}{l}\text { Number of } \\
\text { data points }\end{array}$ & $\begin{array}{c}\text { Observed } \\
\text { mean }(\mathrm{mg} / \mathrm{l})\end{array}$ & $\begin{array}{c}\text { Modeled } \\
\text { mean }(\mathrm{mg} / \mathrm{l})\end{array}$ & RMS error (mg/l) & $\begin{array}{c}\text { Observed change } \\
(\mathrm{mg} / \mathrm{l})\end{array}$ & RER (\%) \\
\hline 1 & L006 & 74 & 30.8 & 15.5 & 33.0 & 226.5 & 14.5 \\
\hline 2 & L001 & 71 & 27.1 & 10.2 & 31.7 & 154.0 & 20.6 \\
\hline 3 & LZ40 & 73 & 44.9 & 14.1 & 42.9 & 142.0 & 30.2 \\
\hline 4 & L005 & 73 & 18.2 & 15.1 & 20.4 & 67.2 & 30.4 \\
\hline 5 & 3RDPTOUT & 62 & 18.5 & 21.9 & 34.3 & 68.0 & 50.5 \\
\hline 6 & KBAROUT & 44 & 12.4 & 47.9 & 71.2 & 100.6 & 70.8 \\
\hline 7 & L002 & 69 & 26.3 & 17.5 & 28.9 & 152.0 & 19.0 \\
\hline 8 & L003 & 73 & 38.3 & 15.7 & 33.9 & 177.3 & 19.1 \\
\hline 9 & L004 & 70 & 40.2 & 15.4 & 52.2 & 391.4 & 13.3 \\
\hline 10 & L007 & 63 & 21.6 & 20.9 & 22.6 & 173.2 & 13.0 \\
\hline 11 & L008 & 73 & 40.6 & 18.4 & 41.2 & 207.4 & 19.8 \\
\hline 12 & LZ2 & 63 & 15.2 & 9.5 & 24.6 & 147.5 & 16.7 \\
\hline 13 & LZ25 & 55 & 19.8 & 11.6 & 23.7 & 123.7 & 19.1 \\
\hline 14 & LZ30 & 73 & 22.2 & 19.4 & 23.6 & 170.5 & 13.8 \\
\hline 15 & LZ42 & 73 & 34.1 & 19.4 & 46.2 & 336.5 & 13.7 \\
\hline 16 & LZ42N & 66 & 17.8 & 18.8 & 24.4 & 65.0 & 37.5 \\
\hline 17 & PALMOUT & 61 & 16.9 & 16.7 & 21.0 & 93.8 & 22.4 \\
\hline 18 & PELMID & 61 & 12.8 & 10.0 & 13.7 & 64.5 & 21.3 \\
\hline 19 & PLN2OUT & 71 & 15.8 & 17.4 & 23.3 & 82.8 & 28.1 \\
\hline 20 & POLE3S & 66 & 13.9 & 13.7 & 18.0 & 84.5 & 21.3 \\
\hline 21 & POLESOUT & 62 & 14.6 & 17.7 & 28.3 & 46.0 & 61.7 \\
\hline 22 & RITAEAST & 69 & 13.7 & 5.9 & 18.3 & 96.5 & 18.9 \\
\hline 23 & RITAWEST & 65 & 15.0 & 14.2 & 19.7 & 122.5 & 16.1 \\
\hline 24 & STAKEOUT & 64 & 15.9 & 18.3 & 26.2 & 63.2 & 41.5 \\
\hline \multirow[t]{2}{*}{25} & TREEOUT & 64 & 18.3 & 18.7 & 26.6 & 95.0 & 28.0 \\
\hline & Total Mean & & 22.6 & 17.0 & 30.0 & 138.0 & 26.5 \\
\hline
\end{tabular}

\section{Aquifer storage and recovery application}

Aquifer storage and recovery is a water management technology/strategy that uses groundwater aquifers to store wet season surface water and then recovers this water later to augment dry season surface water supplies. The Comprehensive Everglades Restoration Plan (USACE 1999) included the hypothetical construction of up to 330 ASR storage wells throughout south Florida, of which 200 were conceptualized for the Lake Okeechobee basin (USACE, 1999). Each well was estimated to have a capacity of 5 million gallons per day. The existing LOEM model was modified to incorporate $\mathrm{SO}_{4}$ predictions specifically to evaluate potential impacts from $\mathrm{SO}_{4}$ loads resulting from a wide scale implementation of ASR technology within the Lake Okeechobee basin. Sulfate water column concentrations play a role in regulating the rate at which mercury becomes methylated in the environment. The results of this LOEM modeling effort will be incorporated into downstream models to predict changes to sulfate concentrations and mercury methylation potential downstream of Lake Okeechobee in the Everglades protection area.

After the LOEM was calibrated and verified for the period of 10 years (3,653 days), from 1 Oct 1999 to 30 Sept 2009 (Ji and Jin 2006; Jin et al. 2007), the model was applied for the same time period to evaluate a variety of hypothetical ASR management scenarios. The proposed ASR inflows/outflows enter or exit the lake at five locations: Kissimmee River, Nubbin Slough, Taylor Creek, Lakeside Ranch, and Port Mayaca (Figure 1). The following ASR scenarios were evaluated: 200 ASR wells in operation from 1 Oct 1999 to 30 Sept 2009, 100 ASR wells in operation from 1 Oct 999 to 30 Sept 2009, and 50 ASR wells in operation from 1 Oct 1999 to 30 Sept 2009. Recent groundwater modeling conducted 
Table 3 Error analysis of observed and modeled chloride (CI) at the 25 stations from 1999 to 2009

\begin{tabular}{|c|c|c|c|c|c|c|c|}
\hline Station number & Station name & $\begin{array}{l}\text { Number of } \\
\text { data points }\end{array}$ & $\begin{array}{c}\text { Observed mean } \\
(\mathrm{mg} / \mathrm{l})\end{array}$ & $\begin{array}{c}\text { Modeled mean } \\
(\mathrm{mg} / \mathrm{l})\end{array}$ & $\begin{array}{c}\text { RMS error } \\
(\mathrm{mg} / \mathrm{l})\end{array}$ & $\begin{array}{c}\text { Observed } \\
\text { change }(\mathrm{mg} / \mathrm{l})\end{array}$ & RER (\%) \\
\hline 1 & L006 & 74 & 62.8 & 65.2 & 9.0 & 51.5 & 17.4 \\
\hline 2 & L001 & 71 & 56.7 & 63.6 & 15.6 & 92.7 & 16.8 \\
\hline 3 & LZ40 & 73 & 62.8 & 64.8 & 8.7 & 49.1 & 17.8 \\
\hline 4 & L005 & 73 & 60.7 & 64.1 & 10.8 & 63.9 & 16.9 \\
\hline 5 & 3RDPTOUT & 62 & 56.2 & 57.5 & 12.4 & 67.3 & 18.4 \\
\hline 6 & KBAROUT & 44 & 47.8 & 38.8 & 19.2 & 79.4 & 24.2 \\
\hline 7 & L002 & 69 & 61.0 & 63.4 & 10.4 & 66.0 & 15.8 \\
\hline 8 & L003 & 73 & 61.5 & 64.4 & 9.9 & 70.7 & 14.0 \\
\hline 9 & L004 & 70 & 63.1 & 65.1 & 8.0 & 56.5 & 14.2 \\
\hline 10 & L007 & 63 & 59.3 & 61.6 & 14.9 & 92.7 & 16.1 \\
\hline 11 & L008 & 73 & 62.8 & 65.0 & 8.4 & 53.6 & 15.8 \\
\hline 12 & LZ2 & 63 & 51.2 & 65.7 & 23.9 & 82.3 & 29.1 \\
\hline 13 & LZ25 & 55 & 63.3 & 62.9 & 10.9 & 42.9 & 25.5 \\
\hline 14 & LZ30 & 73 & 63.0 & 64.7 & 8.5 & 59.9 & 14.2 \\
\hline 15 & LZ42 & 73 & 62.8 & 64.8 & 8.5 & 56.2 & 15.2 \\
\hline 16 & LZ42N & 66 & 56.5 & 60.7 & 12.3 & 75.7 & 16.2 \\
\hline 17 & PALMOUT & 61 & 59.5 & 59.9 & 9.3 & 49.4 & 18.8 \\
\hline 18 & PELMID & 61 & 65.3 & 64.3 & 9.7 & 69.8 & 13.9 \\
\hline 19 & PLN2OUT & 71 & 62.3 & 64.3 & 10.6 & 65.2 & 16.2 \\
\hline 20 & POLE3S & 66 & 64.4 & 63.2 & 10.6 & 54.1 & 19.7 \\
\hline 21 & POLESOUT & 62 & 55.2 & 57.7 & 13.0 & 73.0 & 17.9 \\
\hline 22 & RITAEAST & 69 & 67.5 & 66.8 & 10.8 & 62.3 & 17.3 \\
\hline 23 & RITAWEST & 65 & 66.1 & 63.1 & 9.9 & 59.6 & 16.7 \\
\hline 24 & STAKEOUT & 64 & 55.8 & 59.6 & 12.3 & 76.7 & 16.0 \\
\hline \multirow[t]{2}{*}{25} & TREEOUT & 64 & 60.4 & 60.3 & 11.6 & 118.0 & 9.8 \\
\hline & Total Mean & & 60.3 & 62.1 & 11.6 & 67.5 & 17.4 \\
\hline
\end{tabular}

by the USACE has indicated that the 50 -well scenario may be most realistic (in terms of effects on the regional hydrogeology, groundwater movement, and impacts to existing users); however, for purposes viewing the comparative LOEM model results, the 200, 100 and 50-well scenarios will be presented herein.

The time series of ASR inflow/outflow rate boundary conditions under these three scenarios were created based on the lake stage and lake management rules and general ASR operating scheme as outlined in the Comprehensive Everglades Restoration Plan study (USACE 1999).

Water quality boundary conditions for ASR discharges are also required for the LOEM model. The concentration of chemical constituents in the discharged ASR water depends upon the volume of surface water stored in the aquifer, the percent of stored water recovered, and the quality of the groundwater in the storage zone and the surface water. During recovery, the quality of water recovered from an ASR well changes as more of the stored water is extracted. Essentially, during extended recovery, the water quality begins to reflect less of the original stored surface water and more like the ambient concentrations of constituents in the Floridan aquifer. The most conservative assumption from the perspective of predicting worse case impacts from ASR discharges is to assume that the quality of the recovered water will always be equivalent to an original groundwater quality within the Floridan aquifer, since for critical water quality constituents such as $\mathrm{CL}$ and $\mathrm{SO}_{4}$, the ambient groundwater concentrations significantly exceed the ambient surface water concentrations. For this reason, the water quality boundary conditions for ASR discharges were conservatively estimated as equal to ambient groundwater concentrations for the upper Floridian aquifer in the vicinity of the five ASR locations. It should be noted that during actual 
Table 4 Error analysis of observed and modeled calcium (Ca) at the 25 stations from 1999 to 2009

\begin{tabular}{|c|c|c|c|c|c|c|c|}
\hline Station number & Station name & $\begin{array}{l}\text { Number of } \\
\text { data points }\end{array}$ & $\begin{array}{c}\text { Observed } \\
\text { mean }(\mathrm{mg} / \mathrm{l})\end{array}$ & $\begin{array}{c}\text { Modeled } \\
\text { mean }(\mathrm{mg} / \mathrm{l})\end{array}$ & RMS error (mg/l) & $\begin{array}{c}\text { Observed change } \\
(\mathrm{mg} / \mathrm{l})\end{array}$ & RER (\%) \\
\hline 1 & L006 & 74 & 41.5 & 39.8 & 8.7 & 30.7 & 28.4 \\
\hline 2 & L001 & 71 & 34.2 & 38.5 & 12.8 & 40.5 & 31.6 \\
\hline 3 & LZ40 & 73 & 40.0 & 43.7 & 8.6 & 19.8 & 43.6 \\
\hline 4 & L005 & 73 & 38.5 & 39.3 & 7.6 & 41.6 & 18.3 \\
\hline 5 & 3RDPTOUT & 62 & 36.1 & 37.6 & 10.3 & 28.1 & 36.6 \\
\hline 6 & KBAROUT & 44 & 30.6 & 29.4 & 11.4 & 27.5 & 41.5 \\
\hline 7 & L002 & 69 & 37.0 & 38.5 & 8.8 & 25.7 & 34.2 \\
\hline 8 & L003 & 73 & 39.3 & 39.2 & 9.7 & 41.7 & 23.3 \\
\hline 9 & L004 & 70 & 41.2 & 39.5 & 9.8 & 44.9 & 21.8 \\
\hline 10 & L007 & 63 & 40.6 & 38.8 & 8.2 & 19.5 & 42.4 \\
\hline 11 & L008 & 73 & 41.1 & 39.6 & 8.9 & 36.3 & 24.7 \\
\hline 12 & LZ2 & 63 & 30.8 & 42.8 & 17.2 & 24.3 & 71.1 \\
\hline 13 & LZ25 & 55 & 42.8 & 43.7 & 8.5 & 20.6 & 41.6 \\
\hline 14 & LZ30 & 73 & 41.5 & 43.4 & 8.6 & 23.8 & 36.2 \\
\hline 15 & LZ42 & 73 & 40.7 & 39.9 & 9.1 & 41.2 & 22.1 \\
\hline 16 & LZ42N & 66 & 35.0 & 37.5 & 9.3 & 33.8 & 27.6 \\
\hline 17 & PALMOUT & 61 & 38.0 & 42.0 & 10.2 & 25.3 & 40.4 \\
\hline 18 & PELMID & 61 & 42.3 & 43.7 & 7.9 & 19.9 & 39.9 \\
\hline 19 & PLN2OUT & 71 & 39.5 & 43.3 & 10.6 & 52.0 & 20.5 \\
\hline 20 & POLE3S & 66 & 42.9 & 42.8 & 9.0 & 31.3 & 28.8 \\
\hline 21 & POLESOUT & 62 & 36.8 & 39.2 & 9.6 & 21.0 & 45.8 \\
\hline 22 & RITAEAST & 69 & 42.9 & 46.4 & 10.0 & 41.3 & 24.2 \\
\hline 23 & RITAWEST & 65 & 41.2 & 43.4 & 9.6 & 33.0 & 29.3 \\
\hline 24 & STAKEOUT & 64 & 36.7 & 40.2 & 9.8 & 25.6 & 38.3 \\
\hline \multirow[t]{2}{*}{25} & TREEOUT & 64 & 37.6 & 41.5 & 9.6 & 24.6 & 39.0 \\
\hline & Total Mean & & 38.8 & 40.6 & 9.8 & 30.9 & 34.1 \\
\hline
\end{tabular}

operation, recovery from the ASR wells can be terminated when pre-determined constituent concentrations are observed, based on ecological or lake level considerations. For instance, ASR recovery can be terminated when the recovered water exhibits a chloride concentration of $100 \mathrm{mg} / \mathrm{L}$, or the sulfate concentration reaches $60 \mathrm{mg} / \mathrm{L}$.

After 10 years of ASR operation, the LOEM predicts no significant increase in Ca concentration (Figure 9). This is primarily because the ASR inflow Ca concentrations are similar to ambient concentrations in the lake, so that the added ASR inflow load does not change the $\mathrm{Ca}$ concentration significantly. In contrast, $\mathrm{Cl}$ and $\mathrm{SO}_{4}$ results for the ASR scenarios are significantly different from the base condition. With 200 ASR wells, the LOEM projects $\mathrm{Cl}$ concentrations more than $100 \mathrm{mg} / \mathrm{l}$ higher than the base condition in the summer of 2008 dry period (increase from $50 \mathrm{mg} / \mathrm{L}$ to a range of 150 to $200 \mathrm{mg} / \mathrm{L}$; Figure 9). For the same scenario, the LOEM predicted increases of $\mathrm{SO}_{4}$ concentrations to about $50 \mathrm{mg} / \mathrm{l}$ more than the base condition in the summer of 2008. The primary reason for the $\mathrm{Cl}$ and $\mathrm{SO}_{4}$ increases are that the assumed concentrations of $\mathrm{SO}_{4}$ and $\mathrm{Cl}$ from the ASR wells are directly from the Floridan aquifer and therefore are much higher than the in the Lake, and water levels are lower for these drought periods. In contrast to these increases, after 10 years of ASR operation, the Lake TSS concentration has not changed significantly (Figure 9). This is because ASR discharges have very limited impact on the lake TSS concentration. Figure 9 gives model-data comparisons of $\mathrm{Ca}, \mathrm{Cl}, \mathrm{SO}_{4}$, and TSS at LZ40. The black dots are measured data. The green lines are model results from the benchmark/historical run, which are also presented in Figure 9. The blue lines are the results of the 200 ASR well scenarios, 
Table 5 Error analysis of observed and modeled sulfate (SO4) at the 25 stations from 1999 to 2009

\begin{tabular}{|c|c|c|c|c|c|c|c|}
\hline Station number & Station name & $\begin{array}{l}\text { Number of } \\
\text { data points }\end{array}$ & $\begin{array}{c}\text { Observed } \\
\text { mean }(\mathrm{mg} / \mathrm{l})\end{array}$ & $\begin{array}{l}\text { Modeled mean } \\
(\mathrm{mg} / \mathrm{l})\end{array}$ & $\begin{array}{l}\text { RMS error } \\
(\mathrm{mg} / \mathrm{l})\end{array}$ & $\begin{array}{c}\text { Observed } \\
\text { change (mg/l) }\end{array}$ & RER (\%) \\
\hline 1 & L006 & 74 & 38.0 & 35.7 & 4.0 & 27.2 & 14.8 \\
\hline 2 & L001 & 71 & 31.9 & 35.4 & 10.5 & 44.7 & 23.6 \\
\hline 3 & LZ40 & 73 & 37.2 & 35.6 & 3.8 & 28.7 & 13.5 \\
\hline 4 & L005 & 73 & 34.6 & 35.2 & 4.2 & 40.6 & 10.4 \\
\hline 5 & 3RDPTOUT & 62 & 32.0 & 30.2 & 9.1 & 39.3 & 23.1 \\
\hline 6 & KBAROUT & 44 & 34.5 & 35.1 & 6.5 & 38.2 & 17.2 \\
\hline 7 & L002 & 69 & 35.6 & 34.9 & 4.4 & 28.4 & 15.4 \\
\hline 8 & L003 & 73 & 36.8 & 34.9 & 5.5 & 31.8 & 17.5 \\
\hline 9 & L004 & 70 & 36.8 & 34.3 & 4.8 & 23.8 & 20.2 \\
\hline 10 & L007 & 63 & 36.5 & 35.7 & 4.0 & 29.1 & 13.9 \\
\hline 11 & L008 & 73 & 26.0 & 34.3 & 12.7 & 31.3 & 40.5 \\
\hline 12 & LZ2 & 63 & 41.7 & 36.2 & 8.7 & 31.7 & 27.4 \\
\hline 13 & LZ25 & 55 & 38.0 & 35.5 & 5.2 & 36.7 & 14.1 \\
\hline 14 & LZ30 & 73 & 37.2 & 35.8 & 4.7 & 33.8 & 13.9 \\
\hline 15 & LZ42 & 73 & 32.6 & 33.2 & 6.9 & 39.5 & 17.6 \\
\hline 16 & LZ42N & 66 & 35.3 & 34.1 & 4.6 & 26.4 & 17.5 \\
\hline 17 & PALMOUT & 61 & 39.8 & 36.8 & 4.9 & 24.2 & 20.4 \\
\hline 18 & PELMID & 61 & 36.1 & 35.3 & 4.6 & 37.1 & 12.4 \\
\hline 19 & PLN2OUT & 71 & 40.6 & 35.2 & 9.7 & 41.8 & 23.2 \\
\hline 20 & POLE3S & 66 & 33.2 & 31.5 & 7.6 & 37.2 & 20.6 \\
\hline 21 & POLESOUT & 62 & 45.7 & 38.5 & 18.6 & 111.0 & 16.8 \\
\hline 22 & RITAEAST & 69 & 39.6 & 35.8 & 5.6 & 25.1 & 22.2 \\
\hline 23 & RITAWEST & 65 & 32.1 & 32.4 & 6.9 & 38.5 & 17.9 \\
\hline 24 & STAKEOUT & 64 & 34.0 & 33.7 & 4.2 & 22.5 & 18.9 \\
\hline \multirow[t]{2}{*}{25} & TREEOUT & 64 & 38.0 & 35.7 & 4.0 & 27.2 & 14.8 \\
\hline & Total Mean & & 36.1 & 34.8 & 6.7 & 36.2 & 18.9 \\
\hline
\end{tabular}

the cyan lines are the results of the 100 ASR well scenarios, and the red lines are the results of the 50 ASR well scenario.

Modeled water depth at a nearshore location PALMOUT (location shown in Figure 3 ) is typically between 1 and $2 \mathrm{~m}$ (Figure 10a). Modeled and lake averaged submerged aquatic vegetation (SAV) biomass (Jin and Ji 2013) indicate good correspondence (Figure 10b) On an aerial basis, the model and observed lake SAV distribution are very similar (Figure 10c).

During the summer of 2001, the 200 ASR well scenario increased water depth by about $0.3 \mathrm{~m}$. The increase resulted in an increased SAV biomass (Figure 10b) and SAV area (Figure 10c). The total area of SAV was 39,531 acres on 4 July 2001, an increase of $60 \%$ from the base condition. Similar patterns are observed in the summers of 2007 and 2008. The 100 ASR and 50 ASR well scenarios produced similar patterns but with smaller variation amplitudes (data not shown). Therefore, it is believed that ASR wells can help SAV growth by maintaining higher water depth, when the lake stage is too low for optimum SAV growth (Jin et al., 2011). The beneficial effects of increased SAV biomass resulting from ASR operation needs to be strongly considered when evaluating any perceived negative water quality effects of the recovered water.

The water quality modeling results from the three hypothetical ASR management scenarios are also examined and compared with the historical observed results. Over the period of 10 years (1 Oct 1999 to 30 Sept 2009) at LZ40, the total number of measured data varied from 127 for TP to 36 for SO4 (Table 7). For the purpose of model-data comparison and for consistency, the modeled results at the corresponding data measurement time were also used in calculating the modeled means. The average simulated values for 


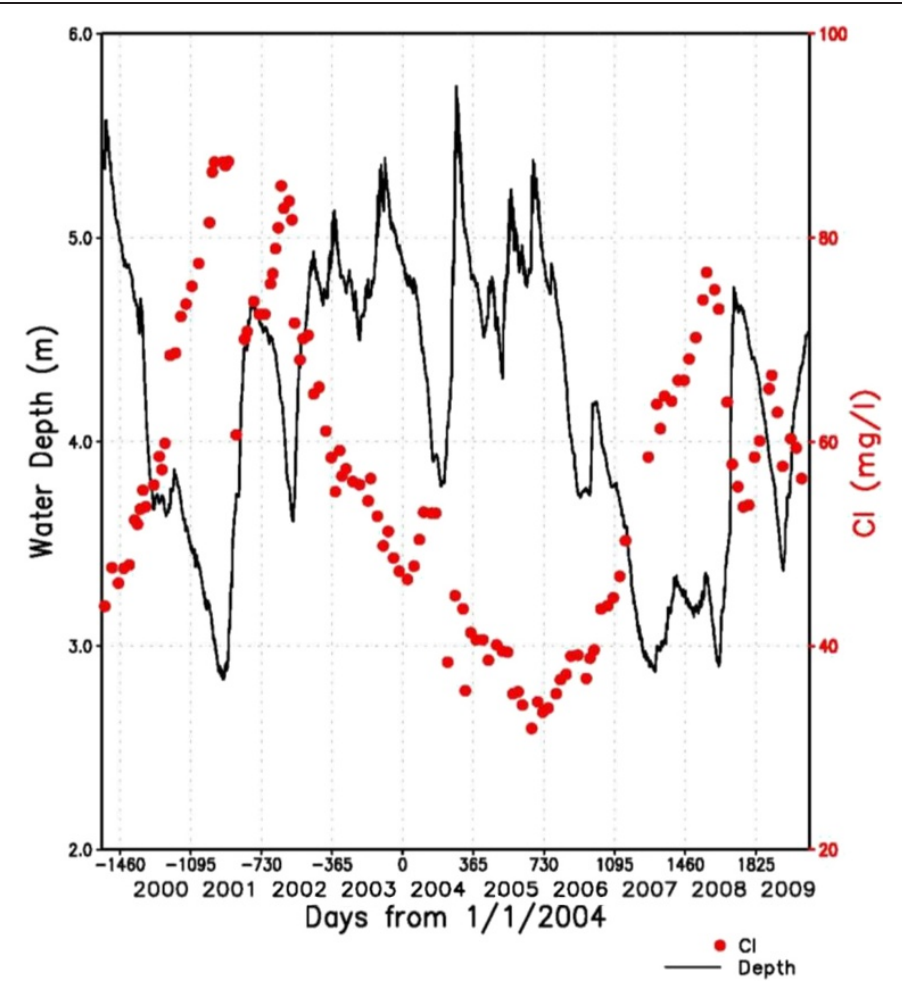

Figure 5 Water depths and chloride concentrations at station LZ40 from 1 Oct 1999 to 30 Sept 2009.

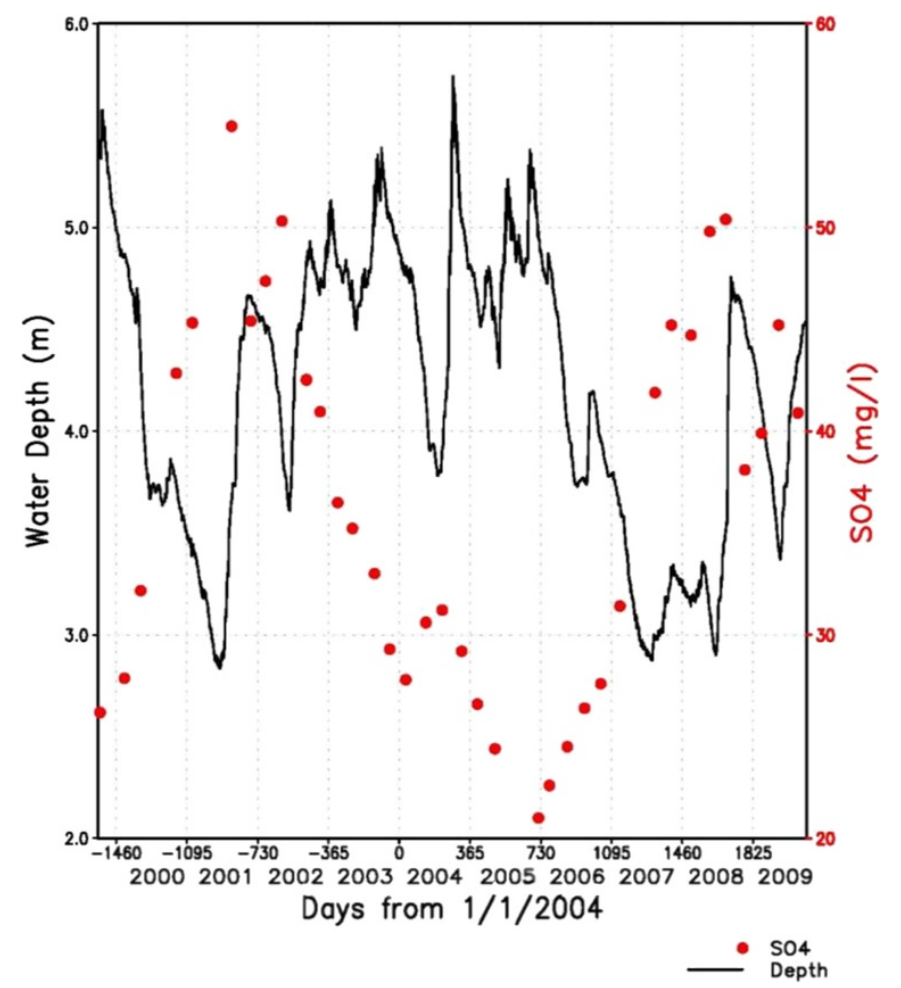

Figure 6 Water depths and sulfate concentrations at station LZ40 from 1 Oct 1999 to 30 Sept 2009. 


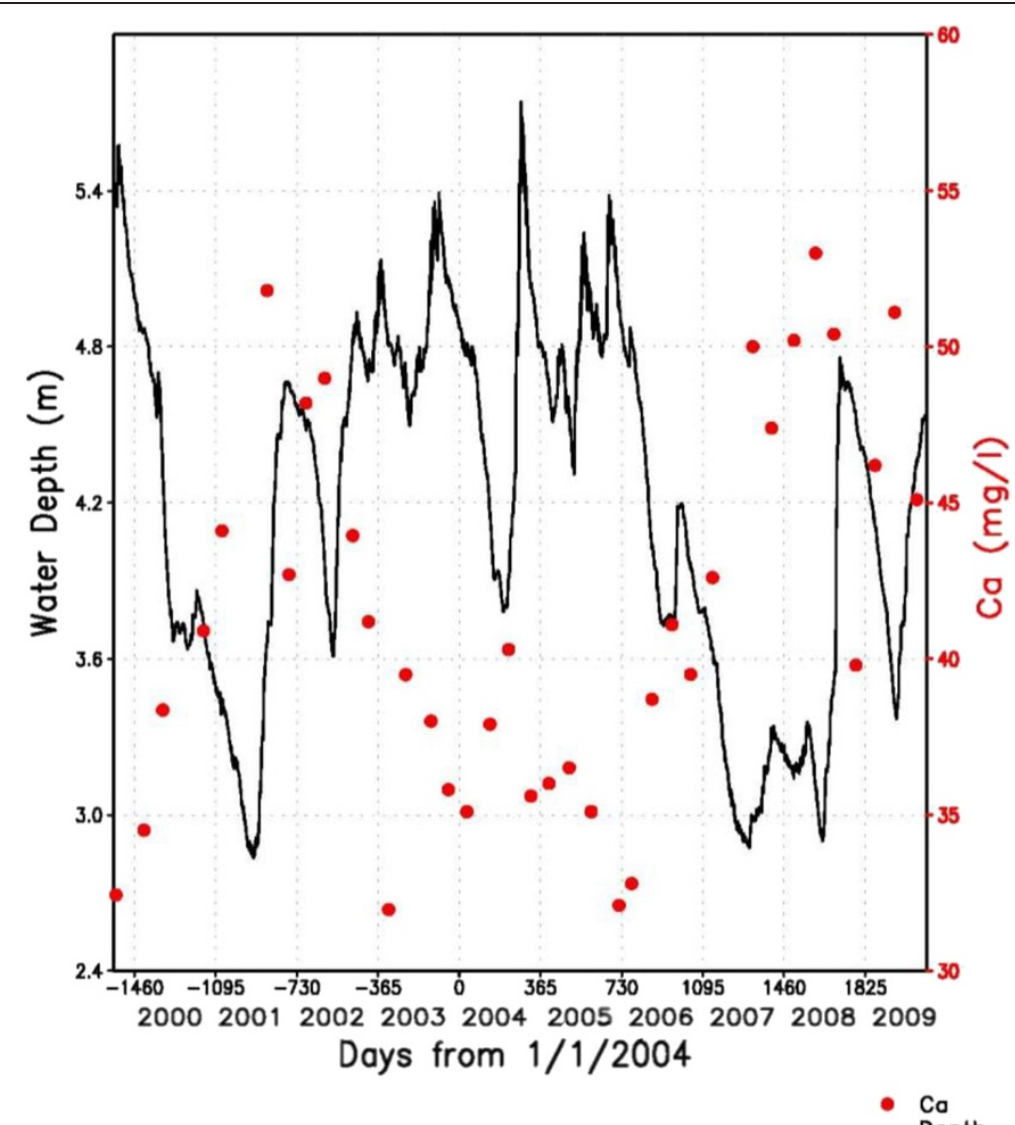

Figure 7 Water depths and calcium at station LZ40 from 1 Oct 1999 to 30 Sept 2009.

DO, Chl-a, TP, SRP, TKN, NOx, TSS, and T do not vary dramatically under the four different scenarios. Statistical analysis and graphical comparison at the other stations lead to similar conclusions (data not shown). Based on these results and given the assumptions inherent in the LOEM model, these water quality parameters should not be altered significantly by the ASR operation. Two factors contributed to this result:

1. Concentrations of the water quality variables from the ASR inflows for nutrients and TSS concentrations are similar to ambient lake concentrations. ASR inflows do not appear to add significant amount of nutrient loadings

Table 6 Correlation coefficients between water depth and Cl, Ca, and SO4 at LZ40 from 1999 to 2009

\begin{tabular}{lcc}
\hline Variable & Lagging days & Correlation coefficient \\
\hline $\mathrm{Cl}$ & 51 & $-0.7 /-0.57$ \\
$\mathrm{Ca}$ & 51 & $-0.72 /-0.83$ \\
$\mathrm{SO} 4$ & 51 & $-0.7 /-0.66$ \\
\hline
\end{tabular}

into the lake. Recent data from the ASR pilot project at the Kissimmee River has indicated that significant reduction in $P$ concentrations may take place via storage in the Floridan aquifer (USACE and SFWMD, 2013).

2. The lake has strong internal cycling of nutrients between the water column and the sediment bed. The nutrients recycled from the bed into the lake water column can often be larger than the amount from the external inflows and become the most important source of nutrient, especially during major hurricane seasons.

The results at station PALMOUT, which is located at the outside edge of the littoral zone, are similar to those at LZ40 (Tables 7 and 8).

A mass balance of CL for the lake under the 200 ASR well scenario was developed (Table 9) which included the following:

- $\mathrm{Cl}$ mass at the beginning of the calendar year $\left(\mathrm{CL}_{\mathrm{ti}}\right)$. For example, at the beginning of 2000, the lake had a total of 2,343,994 metric tons $(\mathrm{t})$ of $\mathrm{Cl}$. 

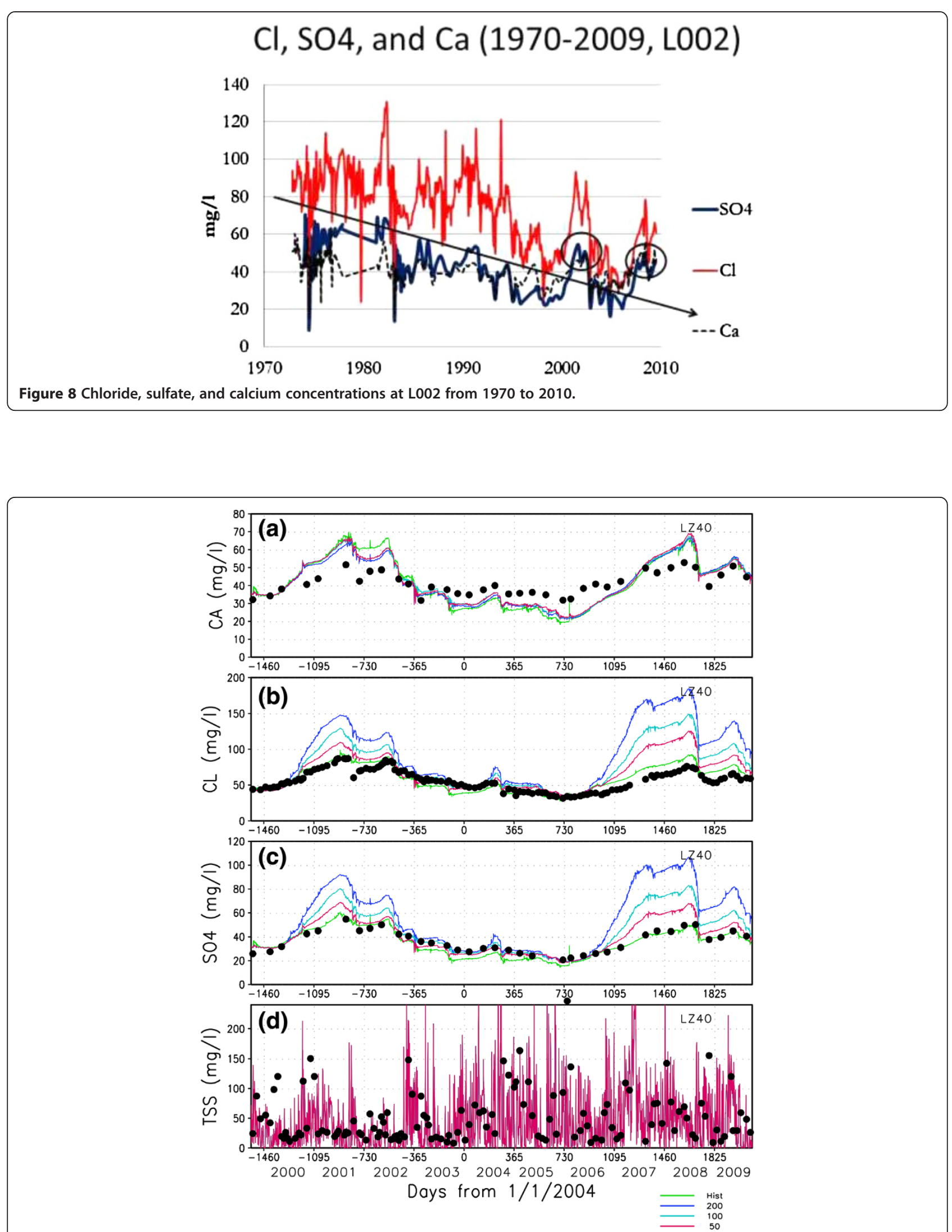

Figure 9 Model-data comparisons. Model-data comparisons of (a) Ca, (b) Cl, (c) SO4, and (d) TSS at LZ40 from 1 Oct 1999 to 30 Sept 2009. 


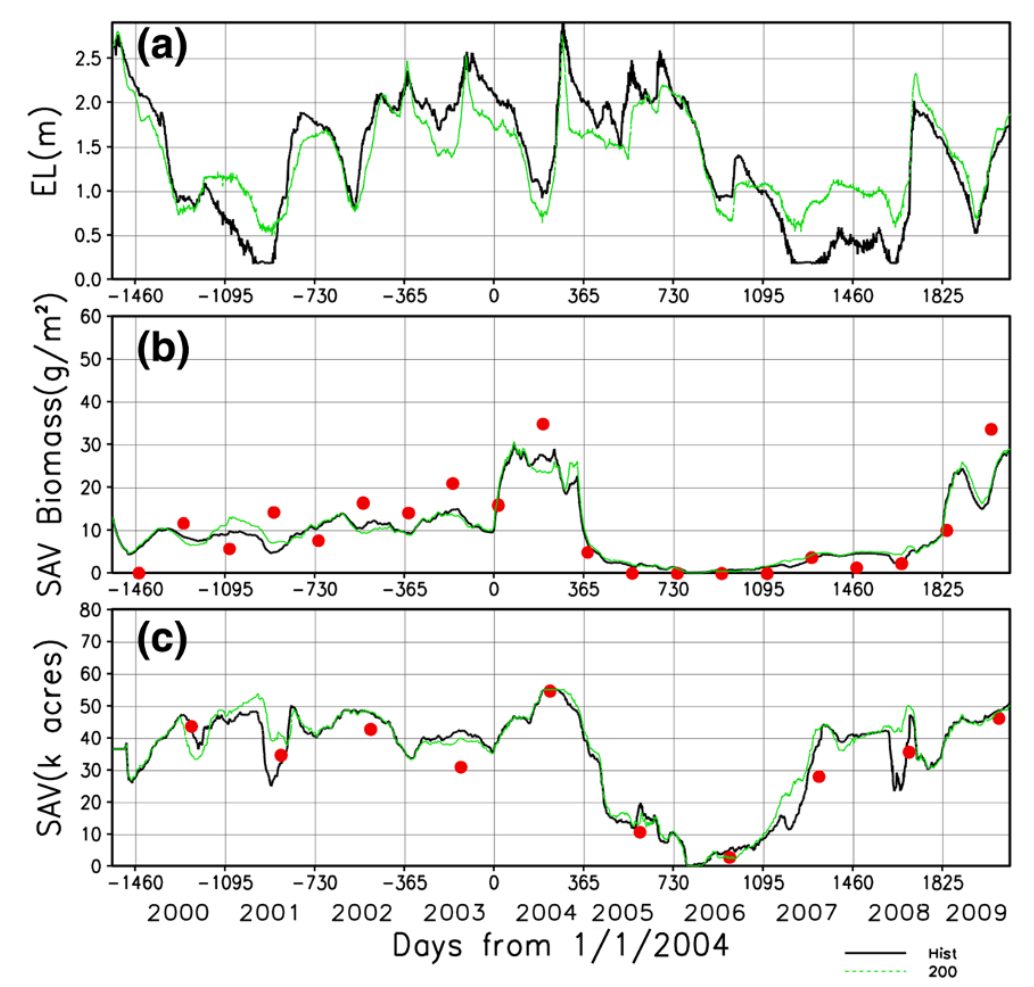

Figure 10 Model-data comparisons. (a) Modeled water depth at PALMOUT (Figure 3), (b) simulated and measured SAV biomass, (c) simulated and measured SAV area. The period is from 1 Oct 1999 to 30 Sept 2009 for 10 years.

- Net load $\left(I_{\mathrm{t}}-O_{\mathrm{t}}\right)$ of $\mathrm{Cl}$ input $\left(I_{\mathrm{t}}\right)$ minus output $\left(O_{\mathrm{t}}\right)$ added through regular the inflows/outflows and ASR wells during the year. For example, during 2000, 171,057 $\mathrm{t}$ of $\mathrm{Cl}$ was added into the lake.

- The end of year result based on input/output calculation was $C_{\mathrm{te}}=C_{\mathrm{ti}}+I_{\mathrm{t}}-O_{\mathrm{t}}$, which is the total estimated $\mathrm{Cl}$ mass at the end of year based on the conservation of mass. For example, in 2000, the estimated $\mathrm{Cl}$ mass at the end of the year should be $405,051 \mathrm{t}$.

- $C_{\text {tem }}$ Model calculated $\mathrm{Cl}$ mass at the end of the year. For example, at the end of 2000, the lake had a total of $411,722 \mathrm{t} \mathrm{CL}_{\mathrm{ti}}$. For example, at the beginning of 2000, the lake had a total of 2,343,994 t of $\mathrm{Cl}$.

- Net load $\left(I_{\mathrm{t}}-O_{t}\right)$ of $\mathrm{Cl}$ input $\left(I_{\mathrm{t}}\right)$ minus output $\left(O_{\mathrm{t}}\right)$ added through regular the inflows/outflows and ASR wells during the year. For example, during 2000, $171,057 \mathrm{t}$ of $\mathrm{Cl}$ was added into the lake.

- The end of year result based on input/output calculation was $C_{\mathrm{te}}=C_{\mathrm{ti}}+I_{\mathrm{t}}-O_{\mathrm{t}}$ of $\mathrm{Cl}$.

- Bias of the LOEM calculation is calculated as bias= $C_{\text {tem }}-C_{\text {te }} / C_{\text {tem }} \times 100$. For example, the LOEM has a bias of $2.8 \%$ in $\mathrm{Cl}$ calculation for the 2000 measured data.

\section{Conclusions}

This manuscript presents the results from the LOEM simulation from 1 Oct 1999 to 30 Sept 2009 with 3,653 days of ASR operations (Jin and Ji 2004, 2005; Jin et al. 2011). The refined, calibrated, and verified LOEM was applied to study water quality and SAV growth (Scheffer, 1989; Scheffer et al. 1994) under three different ASR management scenarios 50, 100, and 200 ASR wells. Major conclusions from this study include the following:

1. During the 10 years of hypothetical ASR operations (1999 to 2009), and assuming that the water recovered from the ASR wells is identical to the ambient water in the Floridan aquifer, the Lake $\mathrm{Ca}$ concentration is not altered significantly compared to the base condition. Also, $\mathrm{Cl}$ concentration can increase by more than $100 \mathrm{mg} / \mathrm{l}$ in the summer; and $\mathrm{SO}_{4}$ concentration can increase by approximately $50 \mathrm{mg} / \mathrm{l}$ in the summer.

2. The variations of the concentrations of $\mathrm{Ca}, \mathrm{Cl}$, and $\mathrm{SO}_{4}$ in the lake from ASR return flows are strongly affected by the ASR well return flow rate and lake volume. Lower water depth and smaller lake volume generally lead to higher 
Table 7 Mean values of observed data and modeled results at LZ40 from 1999 to 2009

\begin{tabular}{|c|c|c|c|c|c|c|}
\hline Parameter name & $\begin{array}{l}\text { Number of } \\
\text { data points }\end{array}$ & Observed mean & Modeled mean (history) & $\begin{array}{c}\text { Modeled mean } \\
\text { (200-well) }\end{array}$ & $\begin{array}{c}\text { Modeled mean } \\
\text { (100-well) }\end{array}$ & $\begin{array}{c}\text { Modeled mean } \\
\text { (50-well) }\end{array}$ \\
\hline $\mathrm{DO}(\mathrm{mg} / \mathrm{l})$ & 121 & 8.081 & 8.663 & 8.665 & 8.658 & 8.649 \\
\hline Chl-a $(\mu \mathrm{g} / \mathrm{l})$ & 122 & 16.179 & 17.321 & 19.231 & 19.004 & 18.894 \\
\hline $\mathrm{TP}(\mathrm{mg} / \mathrm{l})$ & 127 & 0.188 & 0.130 & 0.129 & 0.131 & 0.131 \\
\hline $\mathrm{SRP}(\mathrm{mg} / \mathrm{l})$ & 126 & 0.056 & 0.070 & 0.065 & 0.065 & 0.065 \\
\hline TKN (mg/l) & 127 & 1.486 & 1.298 & 1.419 & 1.432 & 1.438 \\
\hline $\mathrm{NO} 2+\mathrm{NO} 3(\mathrm{mg} / \mathrm{l})$ & 117 & 0.292 & 0.047 & 0.038 & 0.042 & 0.044 \\
\hline TSS (mg/l) & 127 & 51.324 & 39.315 & 29.302 & 31.012 & 32.694 \\
\hline $\mathrm{T}\left({ }^{\circ} \mathrm{C}\right)$ & 126 & 24.263 & 24.592 & 24.650 & 24.655 & 24.640 \\
\hline $\mathrm{Cl}(\mathrm{mg} / \mathrm{l})$ & 125 & 57.577 & 59.104 & 88.888 & 76.528 & 68.430 \\
\hline $\mathrm{Ca}(\mathrm{mg} / \mathrm{l})$ & 37 & 41.322 & 40.951 & 40.994 & 41.668 & 41.859 \\
\hline $\mathrm{sO} 4(\mathrm{mg} / \mathrm{l})$ & 36 & 36.369 & 33.880 & 52.482 & 44.249 & 39.265 \\
\hline
\end{tabular}

The scenarios include historic run, 200-well ASR, 100-well ASR, and 50-well ASR.

Table 8 Mean values of observed data and modeled results at PALMOUT from 1999 to 2009

\begin{tabular}{|c|c|c|c|c|c|c|}
\hline Parameter name & $\begin{array}{l}\text { Number of } \\
\text { data points }\end{array}$ & Observed mean & $\begin{array}{c}\text { Modeled } \\
\text { mean (hist.) }\end{array}$ & $\begin{array}{l}\text { Modeled mean } \\
\text { (200-well) }\end{array}$ & $\begin{array}{l}\text { Modeled mean } \\
(100 \text {-well) }\end{array}$ & $\begin{array}{c}\text { Modeled mean } \\
\text { (50-well) }\end{array}$ \\
\hline $\mathrm{DO}(\mathrm{mg} / \mathrm{l})$ & 107 & 8.387 & 8.353 & 8.575 & 8.524 & 8.465 \\
\hline Chl-a ( $\mu \mathrm{g} / \mathrm{l})$ & 105 & 21.432 & 16.775 & 18.703 & 18.828 & 18.919 \\
\hline $\mathrm{TP}(\mathrm{mg} / \mathrm{l})$ & 109 & 0.101 & 0.123 & 0.128 & 0.129 & 0.128 \\
\hline $\mathrm{SRP}(\mathrm{mg} / \mathrm{l})$ & 83 & 0.037 & 0.064 & 0.063 & 0.063 & 0.063 \\
\hline TKN (mg/l) & 110 & 1.347 & 1.236 & 1.417 & 1.426 & 1.427 \\
\hline $\mathrm{NO} 2+\mathrm{NO} 3(\mathrm{mg} / \mathrm{l})$ & 58 & 0.287 & 0.014 & 0.014 & 0.015 & 0.014 \\
\hline TSS (mg/l) & 95 & 23.094 & 22.454 & 19.795 & 21.628 & 21.224 \\
\hline $\mathrm{T}\left({ }^{\circ} \mathrm{C}\right)$ & 109 & 24.643 & 24.692 & 24.735 & 24.589 & 24.576 \\
\hline $\mathrm{Cl}(\mathrm{mg} / \mathrm{l})$ & 110 & 55.238 & 56.811 & 81.165 & 70.751 & 64.072 \\
\hline $\mathrm{Ca}(\mathrm{mg} / \mathrm{l})$ & 31 & 37.445 & 38.473 & 37.984 & 38.695 & 38.688 \\
\hline $\mathrm{sO} 4$ (mg/l) & 31 & 32.586 & 31.971 & 43.493 & 38.077 & 34.957 \\
\hline
\end{tabular}

The scenarios include historic run, 200-well ASR, 100-well ASR, and 50-well ASR.

Table 9 Mass balance analysis for $\mathrm{Cl}$ under the condition of 200 ASR wells (all units except bias are in metric tons)

\begin{tabular}{lccccc}
\hline Year & Initial lake mass $\boldsymbol{C}_{\mathrm{ti}}$ & Net load $\boldsymbol{I}_{\mathbf{t}}-\boldsymbol{O}_{\mathbf{t}}$ & Final lake mass $\boldsymbol{C}_{\mathrm{te}}$ & LOEM end mass $\boldsymbol{C}_{\mathrm{tem}}$ & Percent bias \\
\hline 2000 & $0.233994 \mathrm{E}+6$ & $0.171057 \mathrm{E}+6$ & $0.405051 \mathrm{E}+6$ & $0.411722 \mathrm{E}+6$ & $0.543693 \mathrm{E}+6$ \\
2001 & $0.411722 \mathrm{E}+6$ & $0.132059 \mathrm{E}+6$ & $0.543781 \mathrm{E}+6$ & $0.410099 \mathrm{E}+6$ & -0.02 \\
2002 & $0.543693 \mathrm{E}+6$ & $-0.116765 \mathrm{E}+6$ & $0.426928 \mathrm{E}+6$ & $0.272714 \mathrm{E}+6$ & -3.1 \\
2003 & $0.410099 \mathrm{E}+6$ & $-0.123002 \mathrm{E}+6$ & $0.287097 \mathrm{E}+6$ & $0.290415 \mathrm{E}+6$ & -3.5 \\
2004 & $0.272714 \mathrm{E}+6$ & $0.215026 \mathrm{E}+11$ & $0.294217 \mathrm{E}+6$ & $0.239610 \mathrm{E}+6$ & -1.4 \\
2005 & $0.290415 \mathrm{E}+6$ & $-0.428658 \mathrm{E}+11$ & $0.247549 \mathrm{E}+6$ & $0.357096 \mathrm{E}+6$ & -2.7 \\
2006 & $0.239610 \mathrm{E}+6$ & $0.114265 \mathrm{E}+6$ & $0.353875 \mathrm{E}+6$ & $0.642641 \mathrm{E}+6$ & $0.584568 \mathrm{E}+6$ \\
2007 & $0.357096 \mathrm{E}+6$ & $0.276897 \mathrm{E}+6$ & $0.633993 \mathrm{E}+6$ & $0.536096 \mathrm{E}+6$ & -2.3 \\
2008 & $0.642641 \mathrm{E}+6$ & $-0.432782 \mathrm{E}+11$ & $0.599363 \mathrm{E}+6$ & $0.546210 \mathrm{E}+6$ & \\
2009 & $0.584568 \mathrm{E}+6$ & $-0.383576 \mathrm{E}+11$ & & & -1.7 \\
\hline
\end{tabular}


concentrations. The correlation coefficients between the water depth and the $\mathrm{Cl}, \mathrm{Ca}$, and $\mathrm{SO}_{4}$ concentrations can be up to $-0.57,-0.83$, and -0.66 , respectively. The variations of these concentrations lag the variations of the water depth by about 51 days.

3. The ASR wells provide water to the lake when the lake stage is low relative to the desired lake management and help maintain higher lake stage (more than 1 foot during dry season). The elevated water depth during the dry season is beneficial to SAV growth in the lake (Jin and Ji 2013).

4. The model results indicate that eutrophicationrelated parameters, such as Chl-a, TP, TKN, and DO will not be significantly affected by ASR operations, although recent findings indicate that ASR may reduce TP via bio-geochemical reactions that take place during storage within the aquifer.

5. The model simulation of ASR well scenarios show increased $\mathrm{Cl}$ and $\mathrm{SO}_{4}$ concentrations in the lake, due to the higher $\mathrm{Cl}$ and $\mathrm{SO}_{4}$ concentrations from the ASR wells. During the dry years, as observed in 2007 and 2008, the 200-well ASR scenario can increase the $\mathrm{Cl}$ concentrations from around $50 \mathrm{mg} / \mathrm{l}$ to a range of 150 to $200 \mathrm{mg} / \mathrm{l}$. This is largely due to the assumed high ASR inflow concentration and significantly reduced lake volume during these drought periods. Recent groundwater modeling by the CERP ASR team has indicated that the 200-well ASR scenario is not achievable due to unacceptable hydrogeologic impacts, and that a 50-well ASR scenario is probably more realistic for future evaluations. An SAV module update for chloride effects on SAV growth might be needed in the future.

The possible interactions between $\mathrm{Ca}, \mathrm{Cl}$, and $\mathrm{SO}_{4}$ with water quality variables are not included in the LOEM. Additional studies are needed to better understand the linkages among these variables.

\section{Competing interests}

The authors declare that they have no competing interests.

\section{Authors' contributions}

KRJ carried out the data analysis and drafted the manuscript. MDS prepared ASR scenarios and boundary condition inputs. ZGJ performed the model runs and statistical analysis. All authors read and approved the final manuscript.

\section{Acknowledgements}

The authors wish to thank the Okeechobee data collection team for collecting the SAV data and Amy Peters for preparing Figures 1 and 3. The authors also wish to thank Tom James, Andy Rodusky, and Bob Verrastro for the review comments.

\section{Author details}

${ }^{1}$ Lead Scientist, South Florida Water Management District, P.O. Box 24680, West Palm Beach, FL 33416-4680, USA. ${ }^{2}$ Senior Environmental Engineer, US Army Corps Engineers, 701 San Marco Blvd, Jacksonville, FL 32207-8175, USA.

${ }^{3}$ Adjunct Professor, Department of Civil Engineering, Catholic University of America, Pangborn Hall, Room G12, Washington, DC 20064, USA.

Received: 1 August 2014 Accepted: 30 October 2014

Published online: 04 December 2014

\section{References}

AEE (2012) CERP ASR Lake Okeechobee submerged aquatic vegetation model enhancement and application. In: Technical report to South Florida water management district. Applied Environmental Engineering, LLC and Camp Dresser \& McKee Inc, Virginia

Aldridge FJ, Phlips EJ, Schelske CL (1995) The use of nutrient enrichment bioassays to test for spatial and temporal distributions of limiting factors affecting phytoplankton dynamics in Lake Okeechobee, Florida. In: Aumen NG, Wetzel RG (eds) Advances in Limnology, Schweizerbart, Stuttgart, Germany

Cerco CF, Cole T (1994) Three-dimensional eutrophication model of Chesapeake Bay. In, vol 1, Main Report. Technical Report EL-94-4. US Army Corps of Engineers Waterways Experiment Station, Vicksburg, MS

Cerco CF, Johnson HJ, Wang HV (2002) Tributary refinements to the Chesapeake Bay model. Technical Report, U.S. Army Corps of Engineers Waterway Experiment Station. ERDC TR-02-4, Vicksburg, MS

CERP (2014), http://www.evergladesplan.org/pm/projects/proj_44_asr_regional.aspx

Chang NB, Yang J, Makkeasorn A, Jin KR, James RT (2012) Spatiotemporal pattern validation of chlorophyll-a concentrations in Lake Okeechobee, Florida, using a comparative MODIS image mining approach. Int J Remote Sens 33 (7):2233-2260

Hamrick JM (1992) Estuarine environmental impact assessment using a threedimensional circulation and transport model. In: Spaulding ML (ed) Estuarine and Coastal Modeling, Proceedings of the 2nd International Conference. American Society of Civil Engineers, New York, pp 292-303

Hamrick JM (1994) Linking hydrodynamic and biogeochemical transport models for estuarine and coastal waters. In: Spaulding ML et al (eds) Estuarine and Coastal Modeling, Proceedings of the 3rd International Conference. American Society of Civil Engineers, New York, pp 591-608

Hamrick JM, Wu TS (1997) Computational design and optimization of the EFDC/HEM3D surface water hydrodynamic and eutrophication models. In: Delich G, Wheeler MF (eds) Next Generation Environmental Model and Computational Methods. Society of Industrial and Applied Mathematics, Philadelphia, pp 143-161

Havens KE, Gawlik DE (2005) Lake Okeechobee conceptual model. Wetlands 25:908-925

Havens KE, James RT (1997) A critical evaluation of phosphorus management goals for Lake Okeechobee, Florida, USA. Lake Reservoir Manag 13:292-301

Havens KE, James RT (1999) Localized changes in transparency linked to mud sediment expansion in Lake Okeechobee, Florida: ecological and management implications. Lake Reservoir Manag 15:54-69

Havens KE, James RT (2005) The phosphorus mass balance of Lake Okeechobee, Florida: implications for eutrophication management. Lake Reservoir Manag 21:139-148

Havens KE, Bierman VJ Jr, Flaig EG, Hanlon C, James RT, Jones BL, Smith VH (1995) Historical trends in the Lake Okeechobee ecosystem VI. Synth Arch Hydrobiol Suppl 107:101-111

Havens KE, Aumen NG, James RT, Smith VH (1996) Rapid ecological changes in a large subtropical lake undergoing cultural eutrophication. Ambio 25:150-155

Havens KE, East TL, Rodusky AJ, Sharfstein B (1999) Littoral periphyton responses to nitrogen and phosphorus: an experimental study in a subtropical lake. Aquat Bot 63:267-290

Havens KE, Beaver JR, East TL, Rodusky AJ, Sharfstein B, Amand AS, Steinman AD (2001) Nutrient effects on producers and consumers in the littoral plankton and periphyton of a subtropical lake. Arch Hydrobiol 152:177-201

Havens KE, Sharfstein B, Rodusky AJ, East TL (2004) Phosphorus accumulation in the littoral zone of a subtropical lake. Hydrobiologia 517:15-24

James RT, Havens KE (2005) Outcomes of extreme water levels on water quality of offshore and nearshore regions in large shallow subtropical lake. Arch Hydrobiol 163:225-239 
James RT, McCormick P (2012) The sulfate budget of a shallow subtropical lake. Fund Appl Limnol 181(4):253-269

James RT, Chimney MJ, Sharfstein B, Engstrom DR, Schottler SP, East T, Jin KR (2008) Hurricane effects on a shallow lake ecosystem, Lake Okeechobee, Florida (USA). Fund Appl Limnol Arch Hydrobiol 172(4):73-287

Ji ZG (2008) Hydrodynamics and water quality: modeling rivers, lakes, and estuaries. Wiley, Hoboken, New Jersey, p 676

Ji ZG, Jin KR (2006) Gyres and seiches in a large and shallow lake. J Great Lakes Res 32:764-775

Ji ZG, Hamrick JH, Pagenkopf J (2002) Sediment and metals modeling in shallow river. J Environ Eng 128:105-119

Jin KANG-REN, Ji Z-G (2001) Calibration and verification of a spectral wind-wave model for Lake Okeechobee. J Ocean Eng 28(5):573-586

Jin KR, Ji ZG (2004) Case study: modeling of sediment transport and wind-wave impact in Lake Okeechobee. J Hydraul Eng ASCE 130(11):1055-1067

Jin KR, Ji ZG (2005) Application and validation of a 3-D model in a shallow lake. $J$ Waterway Port Coast Ocean Eng ASCE 131(5):213-225

Jin KR, Ji ZG (2013) A long term calibration and verification of a submerged aquatic vegetation model for Lake Okeechobee. Ecol Process 2:23

Jin KR, Sun SD (2007) Sediment resuspension and hydrodynamics in Lake Okeechobee during the late summer. J ASCE Eng Mech 133(8):899-910

Jin KR, Wang KH (1998) Wind generated waves in Lake Okeechobee. J AWRA 34 (6): $1-12$

Jin KR, Hamrick JH, Tisdale T (2000) Application of a three-dimensional hydrodynamic model for Lake Okeechobee. J Hydraul Eng ASCE 126:758-771

Jin KR, Ji ZG, Hamrick JH (2002) Modeling winter circulation in Lake Okeechobee, Florida. J Waterway Port Coast Ocean Eng ASCE 128(3):114-125

Jin KR, Ji ZG, James TR (2007) Three-dimensional water quality modeling of a large shallow lake. J Great Lakes Res 33(1):28-45

Jin KR, James RT, Chang NB (2011) Hurricanes affect the sediment and environment in Lake Okeechobee. J Crit Rev Environ Sci Technol 41 (S1):382-394

Kuwabara JS, Topping BR, Coale KH, Berelson WM (1999) Processes affecting the benthic flux of trace metals into the water column of San Francisco Bay. In: Morganwalp DW, Buxton HT (eds) U.S. Geological Survey Ca, Cl, and SO4 Substances Hydrology Program-Proceedings of the Technical Meeting, Charleston, South Carolina, March 8-12, 1999- Volume 2-Contamination of Hydrologic Systems and Related Ecosystems: U.S. Geological Survey Water-Resources Investigations Report 99-4018B

Murphy TK, Yesaki I (1983) Co-precipitation of phosphate and calcite in a naturally eutrophic lake. Limnol Oceanogr 28:58-67

O'conner DJ (1988) Models of sorptive toxic substances in freshwater systems l: basic equations. J Environ Eng 114(3):507-532

Otsubo K, Muraoka K (1987) Field studies on physical properties of sediment and sediment resuspension in Lake Kasumigaura. Jpn J Limnol 48:s131-s138

Phlips EJ, Aldridge FJ, Hansen P, Zimba PV, Inhat J, Conroy M, Ritter P (1993) Spatial and temporal variability of trophic state parameters in a shallow subtropical lake (Lake Okeechobee, Florida, USA). Arch Hydrobiol 128:437-458

Scheffer M (1989) Alternative stable states in eutrophic shallow freshwater systems: a minimal model. Hydrobiol Bull 23:73-85

Scheffer M, Van den Berg M, Breukelaar A, Breukers C, Coops H, Doef R, Meijer ML (1994) Vegetated areas with clear water in turbid shallow lakes. Aquat Bot 49:193-196

SFWMD (2011) DBHYDRO browser user documentation. South Florida Wate Management District, West Palm Beach, FL, p 33406

Tetra Tech (1998) Copper and nickel source characterization for the lower south San Francisco Bay TMDL project, Report prepared for the city of San Jose. Tetra Tech, Inc, Lafayette, California

Tetra Tech (1999) Task 1. Conceptual model report for copper in lower south San Francisco Bay (Final Report), Report prepared for the City of San Jose. Tetra Tech, Inc, Lafayette, California

Tetra Tech (2000) Task 2. Impairment assessment report for copper and nickel in lower south San Francisco Bay (Final Report), Report prepared for the city of San Jose. Tetra Tech, Inc, Lafayette, California

Thomann RV, Mueller JA, Winfield RP, Huang CR (1991) Model of fate and accumulation of PCB homologues in Hudson Estuary. J Environ Eng 117:161-177

Thomann RV, Merklin W, Wright B (1993) Modeling cadmium fate at superfund site: impact of bioturbation. J Environ Eng 119:424-442
USACE (1999) Central and Southern Florida project comprehensive review study: final integrated feasibility report and programatic environmental impact statement. Jacksonville District Army Corps of Engineers, Jacksonville, Florida, USA

USACE, SFWMD (2013) Final technical data report, CERP ASR pilot projects, Kissimmee River ASR system and Hillsboro ASR system

Vermaat JE, Santamaria L, Roos PJ (2000) Water flow across and sediment trapping in submerged macrophyte beds of contrasting growth form. Arch Hydrobiol 148:549-562

\section{doi:10.1186/s13717-014-0024-7}

Cite this article as: Jin et al.: Application and validation of a 3-D calcium, chloride, and sulfate model in Lake Okeechobee. Ecological Processes 2014 3:24.

\section{Submit your manuscript to a SpringerOpen ${ }^{\odot}$ journal and benefit from:}

- Convenient online submission

Rigorous peer review

- Immediate publication on acceptance

- Open access: articles freely available online

- High visibility within the field

- Retaining the copyright to your article

Submit your next manuscript at $>$ springeropen.com 